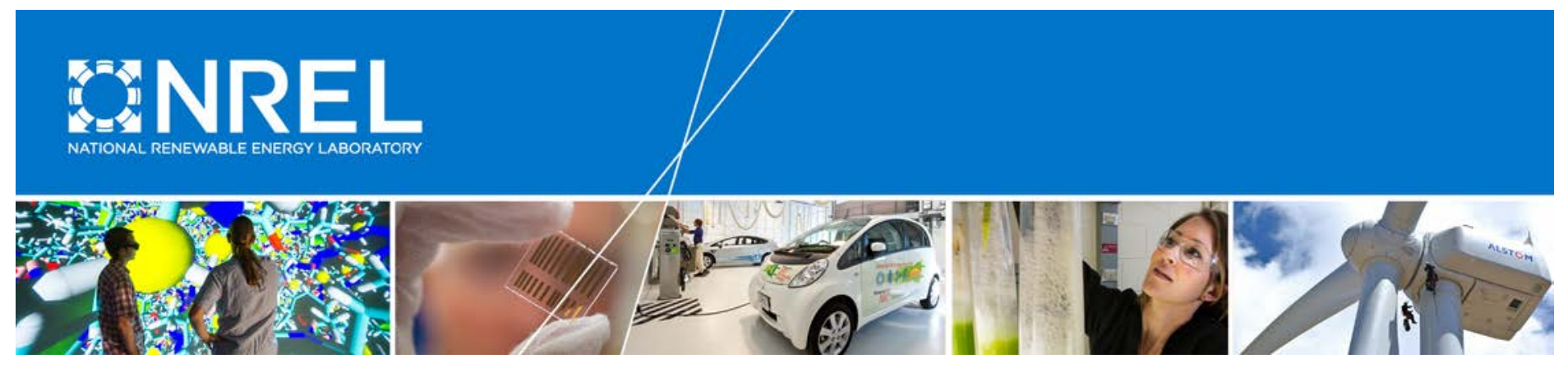

\title{
Unlocking Solar for Low- and Moderate-Income Residents: A Matrix of Financing Options by Resident, Provider, and Housing Type
}

Jeffrey J. Cook and Lori Bird National Renewable Energy Laboratory

NREL is a national laboratory of the U.S. Department of Energy Office of Energy Efficiency \& Renewable Energy Operated by the Alliance for Sustainable Energy, LLC

This report is available at no cost from the National Renewable Energy Laboratory (NREL) at www.nrel.gov/publications.

Technical Report

NREL/TP-6A20-70477

January 2018 


\section{Unlocking Solar for Low- and Moderate-Income Residents: A Matrix of Financing Options by Resident, Provider, and Housing Type}

Jeffrey J. Cook and Lori Bird

National Renewable Energy Laboratory (NREL)

Prepared under Task No. WTSA.10783.01.01.01

NREL is a national laboratory of the U.S. Department of Energy Office of Energy Efficiency \& Renewable Energy Operated by the Alliance for Sustainable Energy, LLC

This report is available at no cost from the National Renewable Energy Laboratory (NREL) at www.nrel.gov/publications.

National Renewable Energy Laboratory 15013 Denver West Parkway Golden, CO 80401

303-275-3000 • www.nrel.gov

\section{Technical Report}

NREL/TP-6A20-70477

January 2018

Contract No. DE-AC36-08GO28308 


\title{
NOTICE
}

This report was prepared as an account of work sponsored by an agency of the United States government. Neither the United States government nor any agency thereof, nor any of their employees, makes any warranty, express or implied, or assumes any legal liability or responsibility for the accuracy, completeness, or usefulness of any information, apparatus, product, or process disclosed, or represents that its use would not infringe privately owned rights. Reference herein to any specific commercial product, process, or service by trade name, trademark, manufacturer, or otherwise does not necessarily constitute or imply its endorsement, recommendation, or favoring by the United States government or any agency thereof. The views and opinions of authors expressed herein do not necessarily state or reflect those of the United States government or any agency thereof.

This report is available at no cost from the National Renewable Energy Laboratory (NREL) at www.nrel.gov/publications.

Available electronically at SciTech Connect http:/www.osti.gov/scitech

Available for a processing fee to U.S. Department of Energy and its contractors, in paper, from:

\author{
U.S. Department of Energy \\ Office of Scientific and Technical Information \\ P.O. Box 62 \\ Oak Ridge, TN 37831-0062 \\ OSTI http://www.osti.gov \\ Phone: 865.576.8401 \\ Fax: 865.576.5728 \\ Email: reports@osti.gov
}

Available for sale to the public, in paper, from:

\author{
U.S. Department of Commerce \\ National Technical Information Service \\ 5301 Shawnee Road \\ Alexandria, VA 22312 \\ NTIS http://www.ntis.gov \\ Phone: 800.553 .6847 or 703.605 .6000 \\ Fax: 703.605.6900 \\ Email: orders@ntis.gov
}




\section{Acknowledgements}

This work was prepared by the National Renewable Energy Laboratory (NREL) for the Clean Energy States Alliance (CESA), under TAS-16-891, State Strategies to Bring Solar to Low-and Moderate-income Communities. The authors would like to thank the following individuals for their insights regarding financing options for low-and moderate-income customers including: Tim Beal (Boulder Housing Partners), Crystal Bergemann (U.S. Department of Housing and Urban Development), Joshua Olsen (U.S. Department of Energy), Brigid Ryan (Rhode Island Housing), Wayne Waite (Waite \& Associates), Diana Chace, Nate Hausman, Warren Leon, and Todd Olinsky-Paul (CESA), and Urken Edy, Yael Gichon, Kristin Hyser, Crystal Launder, and Kendra Tupper (City of Boulder). We also would like to thank Christina Volpi and Stacy Buchanan of NREL for their figure and graphic design as well as Eve Armour for her technical editing. 


\section{Executive Summary}

Historically, the low-and moderate-income (LMI) market has been underserved by solar photovoltaics (PV), in part because of the unique barriers to participation in the PV market that LMI residents face. In addition to other barriers, they often rent, have lower credit scores, and have limited funds to make up-front investments in PV. Some states have adopted innovative financing programs to provide LMI residents with access to PV, but the applicability and effectiveness of financing strategies can vary, depending on the type of housing and the customer's homeownership status.

The intent of this report is to identify the most promising strategies state policymakers might consider using to finance PV for LMI customers across three housing types: single family, multifamily, and manufactured housing. In this report, we examine 13 financing options that could be used to serve LMI residents and each has different impacts that are related to state administration and LMI market deployment. Policymakers will need to weigh these and other potential impacts when designing programs to serve the LMI market.

In general, the variables that influence which of these financing options may be most preferable for certain LMI residents are housing type, ownership status, and whether the resident receives federal housing assistance. LMI homeowners in single-family dwellings have the greatest opportunity to install on-site PV because they have authority to make decisions that impact the home. In comparison, tenants have fewer opportunities to pursue on-site solar because they lack this authority. Nevertheless, tenants may be able to pursue off-site options, such as community solar. Similarly, homeowners in multi-family or manufactured housing where the resident may not own portions of the roof, lot, or common areas, may need to seek community solar unless the housing provider is interested in on-site PV.

LMI residents in federally subsidized housing face additional challenges that are related to project approval and benefit distribution. Millions of LMI residents live in federally assisted housing of all types provided by the U.S. Department of Housing and Urban Development (HUD) or by private landlords that leverage the Low-income Housing Tax Credit (LIHTC) (White 2012; HUD 2017c; 2017f). For certain HUD-assisted housing, on-site PV projects need to be approved by HUD. In addition, the benefits of on-site or off-site solar may need to be shared with HUD depending upon how utility allowances are structured.

Table ES-1 identifies the first- and second-tier financing options for homeowners or building owners in single-family, multi-family, and manufactured housing as well as for community solar. The first-tier options were selected based on their potential impact on LMI PV deployment. Second-tier financing approaches could also be used to achieve state policy goals, but they may not have as much effect on the relevant LMI market segment. However, some first-tier options may come at a significantly higher cost to the state than lower tier options. As a result, state policymakers may wish to weigh these tradeoffs when deciding about which financing approaches are best suited to achieving their LMI PV deployment goals. 


\section{Table ES-1. Comparison of Financing Options by Resident, Housing Provider, or Developer}

\begin{tabular}{|c|c|c|c|c|c|}
\hline $\begin{array}{l}\text { Financing } \\
\text { Option }\end{array}$ & $\begin{array}{l}\text { Single-Family } \\
\text { Housing } \\
\text { (Owner- } \\
\text { Occupied) }\end{array}$ & $\begin{array}{l}\text { Multifamily } \\
\text { Housing } \\
\text { Provider }\end{array}$ & $\begin{array}{l}\text { Manufactured } \\
\text { Housing } \\
\text { Provider }\end{array}$ & $\begin{array}{c}\text { Any LMI Tenant } \\
\text { or Homeowner } \\
\text { (Community } \\
\text { Solar) }\end{array}$ & $\begin{array}{c}\text { Community } \\
\text { Solar } \\
\text { Developer }\end{array}$ \\
\hline \multicolumn{6}{|l|}{$\begin{array}{l}\text { Bulk } \\
\text { Purchasing }\end{array}$} \\
\hline \multicolumn{6}{|l|}{$\begin{array}{l}\text { Capital } \\
\text { Refinancing }\end{array}$} \\
\hline \multicolumn{6}{|l|}{ Crowdfunding } \\
\hline \multicolumn{6}{|l|}{$\begin{array}{l}\text { Direct Cash } \\
\text { Incentives }\end{array}$} \\
\hline \multicolumn{6}{|l|}{ Solar Hosting } \\
\hline \multicolumn{6}{|l|}{ Loans } \\
\hline \multicolumn{6}{|l|}{ LIHEAP/WAPa } \\
\hline \multicolumn{6}{|l|}{ Net Metering } \\
\hline \multicolumn{6}{|l|}{$\begin{array}{l}\text { On-bill } \\
\text { Financing }\end{array}$} \\
\hline \multicolumn{6}{|l|}{ PACE } \\
\hline \multicolumn{6}{|l|}{$\begin{array}{l}\text { Production } \\
\text { Incentives }\end{array}$} \\
\hline \multicolumn{6}{|l|}{ Tax Incentives } \\
\hline \multicolumn{6}{|l|}{$\begin{array}{l}\text { Third-party } \\
\text { Leasing/ESA }\end{array}$} \\
\hline \multicolumn{4}{|c|}{ a Low-Income Home Energy Assistance Program/Weatherization Assistance Program } & \multicolumn{2}{|c|}{$\underset{\text { N/A SecondTier First Tier }}{\longrightarrow}$} \\
\hline
\end{tabular}

Though the focus of this report is on the top financing options for various housing types, this is not to suggest these options will always be the best pathways to serve the LMI market. In reality, projects may rely on a variety of financing options, so a project's individual context may dictate which types of incentives are most appropriate. The table above is designed to be used as a screening tool that may help guide policymakers considering how best to serve the LMI market. 


\section{Table of Contents}

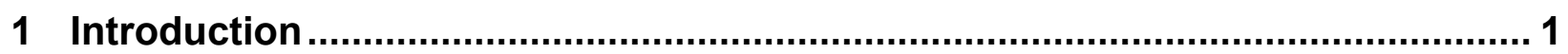

2 Overview and Comparison of General Financing Strategies ............................. 3

3 Considerations for Federally Supported Housing …............................................. 8

3.1 HUD-Subsidized Housing ............................................................................................ 8

3.1.1 Public Housing .........................................................................................................

3.1.2 Project-Based Rental Assistance ........................................................................... 9

3.1.3 Tenant-Based Rental Assistance …………………………....................................... 10

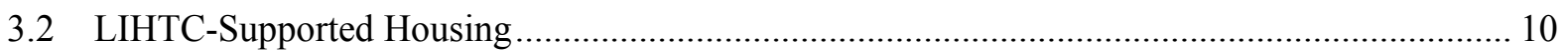

3.3 Summary of Subsidized Housing Financing Considerations …………………………….......... 11

4 Top Financing Options by Housing Type …..................................................... 12

4.1 Single-Family Homes................................................................................................. 12

4.1.1 Financing Options for LMI Single Family Owner-occupied Homes .............................. 12

4.1.2 Financing Options for Single-Family Home LMI Tenants ………………………….... 16

4.2 Multifamily Housing ........................................................................................................ 17

4.2.1 Financing Options for Multifamily Housing Providers................................................. 18

4.2.2 Financing Options for Multifamily LMI Residents ……………………………….... 22

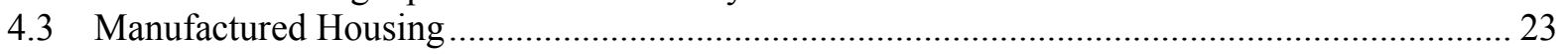

4.3.1 Financing Options for Manufactured Housing Providers ……………………………...2 24

4.3.2 Financing Options for Manufactured Housing LMI Residents .................................... 26

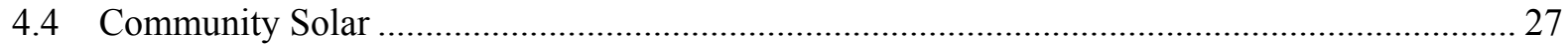

4.4.1 Financing Options for Community Solar LMI Participants ........................................ 27

4.4.2 Financing Options for Community Solar Developers ................................................... 31

5 Summary Matrix of Financing Options …......................................................... 34

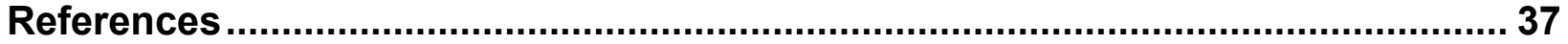




\section{List of Figures}

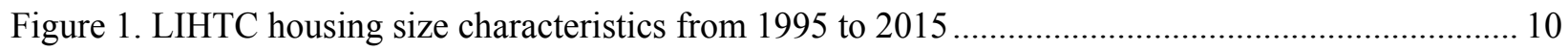

\section{List of Tables}

Table ES-1. Comparison of Financing Options by Resident, Housing Provider, or Developer .................. v

Table 1. Comparison of State Administration and LMI Market Considerations Across Certain

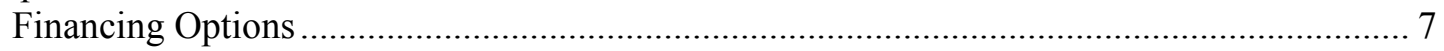

Table 2. Advantages and Disadvantages of Selected On-site PV Financing Structures for Owner-

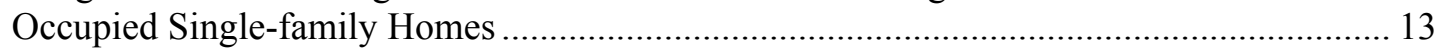

Table 3. Advantages and Disadvantages of Selected Financing Structures for Multifamily Providers ..... 18

Table 4. Advantages and Disadvantages of Selected Financing Structures for Manufactured

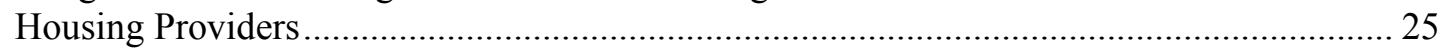

Table 5. Advantages and Disadvantages of Selected Financing Structures for LMI Participants in

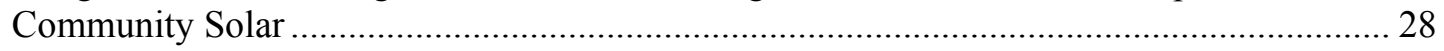

Table 6. Advantages and Disadvantages of Selected Financing Structures for Community Solar

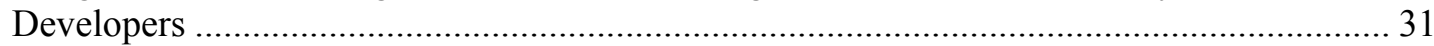

Table 7. Comparison of First Tier Financing Options by Resident, Housing Provider, or Developer

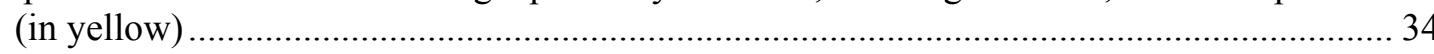

Table 8. Comparison of Financing Options by Resident, Housing Provider, or Developer....................... 36 


\section{Introduction}

More than 2.6 gigawatts of rooftop photovoltaic (PV) capacity has been installed on homes across the United States (Perea et al. 2017). Most systems have been installed at homes of middle- to higher-income families, while lower-income households are under-represented among PV adopters (Barbose et al. 2017; Ronen et al. 2016). In addition, 343 megawatts (MWs) of community solar projects have been installed across the country (Honeyman, Shia, and Krulewitz 2017). Historically, low-income households have not been targeted in these programs either, but recently states have designed policies to require or incentivize developers to subscribe low-income residents (Paulos 2017; Lotus Engineering and Sustainability LLC 2015). As a result, though LMI residents could benefit from PV to reduce their energy burden, these customers historically have been underserved by on-site (rooftop and ground-mounted) and offsite (community solar) PV.

There are a variety of factors that help explain why LMI customers have not adopted PV including the condition of a home, the resident's homeownership status, and financing challenges. First, two thirds of LMI customers live in homes built before 1970 (Clean Energy Advisory Council 2017). This can be problematic for rooftop PV applications because of the older roofs and the potential need for electrical system or other upgrades before PV can be installed. Though these issues also impact higher-income residents, the added cost of these retrofits are more likely to be cost-prohibitive for LMI residents.

Second, most LMI customers suffer from an ownership barrier. Overall, $49 \%$ of households with less than the national median family income own their homes, as compared to $78 \%$ of households with incomes greater than or equal to the median income (U.S. Census 2017). Ownership status can have a significant impact on the PV and financial options available to residents. Unlike renters, homeowners have the authority to make on- and off-site PV installation decisions and assume the risks and benefits associated with those systems. In situations where an occupant is renting from a private landlord, the renter might not have the same authority to approve on-site installations. If the renter lives in public housing or receives U.S. Housing and Urban Development (HUD) rental assistance, HUD and the landlord would have to approve the project. If any of these entities reject the installation, a renter could not pursue an on-site system. Depending on the renter's housing type, it may be possible to pursue an off-site option such as community solar. This option presents its own challenges, particularly challenges relating to benefit distribution and metering of a building.

Third, LMI homeowners face financial challenges in procuring either rooftop PV or off-site solar. While higher income customers may be able to pay for either project upfront, most LMI customers lack the funds to make the initial investment. In addition, if higher income residents do not have the means or funds to purchase a system, they can pursue private or developer financing. In comparison, LMI customers may have lower credit scores and thus have limited access to the same financers (Center for Social Inclusion, GRID Alternatives, and Vote Solar 2016).

Finally, LMI customers have limited tax liabilities and may not benefit from certain tax credits in the same manner as higher income individuals. Collectively, these challenges make it difficult for LMI customers to benefit from rooftop or off-site PV (e.g., community solar). 
States have taken a variety of approaches to address these barriers, including a range of financing programs tailored to the needs of LMI residents. Even within the same state, different housing arrangements can influence whether LMI residents can leverage certain financing options for PV deployment. And though there are many housing arrangements, three general categories ${ }^{1}$ are explored for further analysis in this report:

- Single-family housing is a housing unit that is designed for one household or family that may be detached from or attached to another housing unit.

- Multifamily housing is a building with two or more residential units.

- Manufactured housing is a residential structure that is transportable in one or more parts and is built on a permanent chassis and used primarily as a residence.

The intent of this report is to compare financing options that state policymakers might consider for achieving their LMI PV deployment goals and identifying the most promising strategies based on LMI housing type and ownership status. The report is structured as follows:

- Section 2-summarizes and compares the general financing options included in this report based on state administration and LMI market considerations.

- Section 3-documents the unique impacts federal assistance can have on the financing approaches available across housing types.

- Section 4-describes each of the three housing categories, the unique challenges that LMI customers face with adopting PV, and offers a comparison of relevant top financing options for homeowners, renters, and building providers.

- Section 5-summarizes the information in Section 4 and includes a financing matrix to clarify and compare all financing options across housing types. This matrix can then be used by state policymakers as a reference to help inform their PV policy decisions.

${ }^{1}$ These housing types were generated from the common housing types documented in the U.S. Energy Information Administration (EIA) Residential Energy Consumption Survey (see EIA 2017). 


\section{Overview and Comparison of General Financing Strategies}

There are a variety of financing options available across the country to support PV adoption. This study examines 13 financing options that could assist with solar deployment in LMI populations. These financing options were identified based on a review of the literature and are defined as follows:

- Bulk purchasing allows interested parties to join each other to purchase multiple PV systems all at once, at a lower cost. Solarize Connecticut's bulk purchasing program has installed systems at $25 \%$ less cost than standalone systems, but this and other programs, such as Solarize Rhode Island, have not targeted LMI customers (Paulos 2017). ${ }^{2}$

- Capital refinancing is an approach where a building owner negotiates a new mortgage rate and term to generate additional capital for building improvements including PV (Clean Energy Advisory Council 2017). This financing structure is more commonly available to owners of large, multifamily housing. To help facilitate the use of these mortgage loans for the revitalization of some multifamily housing, the Connecticut Green Bank offers a catalyst financing program that is meant to fill funding gaps for large-scale energy projects from this sector (Connecticut Green Bank 2017c). HUD also offers a Mortgage Insurance for Rental and Cooperative Housing program that can be used to support energy projects (HUD 2017i). There is anecdotal evidence of the capital refinancing process being used to deploy PV, but its use is not widespread.

- Crowdfunding is a financing approach where capital is sourced largely from donations from the public rather than from accredited investors. There are some notable projectlevel successes, as demonstrated by Solar Mosaic and RE-volv (Paulos 2017), but given the voluntary nature of this approach it may only be successful in case-by-case applications.

- Direct cash incentives are payments or reimbursements such as grants or rebates for the deployment of PV. For example, California offers rebates via the Single-family Solar Housing (SASH) and Multifamily Solar Housing (MASH) programs (California Public Utilities Commission 2017a, 2017b). For some LMI customers, SASH rebates cover the entire cost of the system. ${ }^{3}$

- Loans from public or private financial institutions often under-subsidized terms have been used to deploy PV. The Massachusetts Solar Loan Program is one example, where the state has set aside $\$ 30$ million in funding to enable cash-flow positive loans between private lenders and LMI customers (Executive Office of Energy and Environmental Affairs 2017a). To date, this program has underwritten approximately 1,000 loans representing a total capacity of $8 \mathrm{MW}$ (Lowder 2017).

\footnotetext{
2 Though no state has integrated an LMI component into a bulk purchasing program, the Philadelphia Energy Authority (2017) intends to launch a program in January 2018 that addresses this market segment.

${ }^{3}$ For more information, see "Appendix D: Single-Family Affordable Solar Homes (SASH) 2.0 Program Handbook" at http://www.gosolarcalifornia.ca.gov/documents/SASH_Handbook.pdf.
} 
- Low Income Home Energy Assistance Program (LIHEAP)/Weatherization Assistance Program (WAP) are two Department of Energy (DOE) programs that allow states to use program dollars to install cost-effective PV. For example, California used some LIHEAP funds in a pilot study to provide solar to LMI customers (Paulos 2017). In addition, Colorado is using WAP and LIHEAP dollars to install rooftop PV on WAPeligible LMI households (Higgins, Brooks, and Lehermeier 2016).

- Net metering is a compensation structure for the excess generation produced from PV systems, where customers are credited on their utility bill for system output. Forty-one states have net metering programs for rooftop projects, while a few have also adopted virtual net metering, where customers can receive bill credits for off-site PV. ${ }^{4}$ In either design, net metering programs typically do not address up-front cost barriers that may preclude LMI customer access. To address this issue, states could incorporate an additional incentive (or adder) for certain on or off-site LMI projects.

- On-bill financing is a funding structure where a third party (in some cases the utility) pays for the up-front costs of a PV system and the resident pays for the investment through monthly electricity bills. On-bill financing programs are operated across 32 states, though typically for energy efficiency projects (NCSL 2015). In some cases, onsite PV projects are eligible, while there is at least one example of on-bill financing for community solar offered by the Colorado-based electric cooperative Grand Valley Power (Kaufmann 2015).

- Production incentives are generation-based incentives for the output of PV systems. These incentives can be fixed or varied based on market prices, which is often the case with Solar Renewable Energy Credit (SREC) incentive programs. Some incentive programs have been designed to support LMI PV adoption including Massachusetts' SREC-II program. In this program, generation from an LMI-related project qualified for full SREC compensation, while other eligible projects qualified for $70 \%-90 \%$ SREC compensation (Executive Office of Energy and Environmental Affairs 2017b). Massachusetts has proposed new performance incentives that if finalized would further compensate LMI-related projects. ${ }^{5}$

- Property assessed clean energy (PACE) allows customers to pay for a PV installation through a property tax bill. These payments take priority over mortgages, reassuring private lenders that associated loans will be repaid in certain situations. The state of California has the most robust residential PACE market and has adopted a loan loss reserve for first-mortgage holders to recoup possible losses associated with the PACE loan (Leventis et al. 2016). Though PACE programs have typically been used for singlefamily homes, at least one project in California leverages PACE in a manufactured housing context (CleanFund 2017).

- Solar hosting is an approach where a third party pays a homeowner to install and operate rooftop PV. The third party owns the system and its generation. For example, Los Angeles Department of Water and Power offers a $\$ 30$ monthly bill credit to participating

\footnotetext{
${ }^{4}$ See the Database of State Incentives for Renewables and Efficiency (http://www.dsireusa.org/ ).

${ }^{5}$ See proposed program regulations "225 CMR: Department of Energy Resources: 225 CMR 20.00: SOLAR Massachusetts Renewable Target (SMART) Program" (http://www.mass.gov/eea/docs/doer/rps-aps/225-cmr-20-00draft.pdf).
} 
customers who allow them to install a rooftop PV system on their home (Penn 2016). Arizona Public Service also offers a solar hosting program with an annual $\$ 360$ bill savings, but the program is currently full (APS 2017).

- Tax incentives can be designed to allow a residential homeowner or multifamily housing provider to deduct a portion of the cost of a PV system from a tax bill. ${ }^{6}$ For instance, Oregon offers the Residential Energy Tax Credit that provides a credit up to $50 \%$ of the net cost of the system for eligible LMI customers. ${ }^{7}$ This approach reduces the overall cost of the PV system, but does not reduce the full up-front cost. In addition, some tax credits can only be used to offset a taxpayer's annual tax liability. If the full credit exceeds a filer's tax liability, the excess is not paid and instead is carried forward to offset future years' tax liabilities. In the case of Oregon's program, these credits can be carried over for five years. Outside these incentives to LMI customers, multifamily housing providers or other stakeholders may also have the opportunity to leverage certain federal tax credits such as the Business Energy Investment Tax Credit (ITC) and the New Markets Tax Credit to reduce the overall cost of a PV system. ${ }^{8}$ Project developers may also wish to work with local and regional banks

- Third-party leasing/energy service agreements (ESA) allow an LMI customer or multifamily housing provider to contract with a third-party contractor to fund, construct, and operate a PV system. The benefits of the PV system are then distributed (based on contracted terms) to the participating customer and contractor. Third-party leasing of a solar project, typically through a power purchase agreement, is prohibited in nine states and its legality is unclear in another 15, but for the remaining 26 states this option is available (Paulos 2017). Often, individual LMI customers have not been targeted for leasing programs. This is partly because of concerns over lower credit scores. When this structure has been paired with other LMI incentives, it has been successful, as is the case in California (see Solar Hosting description listed above). In comparison, many multifamily providers, including public housing authorities, have frequently used ESAs to deploy solar (HUD 2017j).

States should evaluate a variety of factors before adopting a financing program to support LMI PV systems and this report focuses on five key considerations divided into two categories state administration and LMI market considerations (See Table 1). For states, the ease of implementation and potential for external investment are two useful screens for LMI-related financing options. Given limited state resources, policymakers may be more interested in developing programs that rely on private sector participation or can be integrated into existing state agency programs. This is because a state may not have the administrative capacity to launch new programs. In line with this concern, states may also be interested in financing options that foster private sector or other third-party funding (i.e., federal government, private sector, or

\footnotetext{
${ }^{6}$ For more information on this tax credit, see "Business Energy Investment Tax Credit (ITC)" at https://energy.gov/savings/business-energy-investment-tax-credit-itc.

${ }^{7}$ For more information on this tax credit, see "Residential Energy Tax Credit" at http://programs.dsireusa.org/system/program/detail/638.

${ }^{8}$ For more information on the ITC, see "Business Energy Investment Tax Credit (ITC)" at https://energy.gov/savings/business-energy-investment-tax-credit-itc and for more information on the NMTC, see "New Markets Tax Credit Program" at https://www.cdfifund.gov/programs-training/Programs/new-markets-taxcredit/Pages/default.aspx. ${ }^{8}$
} 
nonprofits). Being able to partner with third-party contractors to fund programs can reduce the budget requirement on the state, while potentially expanding the impact of the program to reach more of the LMI market.

Though these administration considerations are important, policymakers may also want to evaluate how different financing options influence the LMI market. This report describes three key LMI market considerations including up-front cost impact, customer benefit, and market potential.

A financing mechanism's impact on reducing the up-front cost of PV is important because many LMI customers do not have the resources to invest in these systems. As a result, LMI customers may not be attracted to financing programs that do not address these costs. In addition to addressing this up-front barrier, policymakers may also want to consider how LMI customers benefit from the financing approach. Those approaches that offer more reductions in LMI resident energy burden may be more attractive to policymakers as well as LMI customers. Finally, these financing options are likely to have varying market potential. Understanding this variation may be important to policymakers as a means to understand how different options may achieve their LMI deployment goals. Note that estimating the exact market potential is outside the scope of this report, instead we qualitatively compare the financing options based on current trends in the market to offer some perspective on how each might be used to foster LMI PV deployment.

Table 1 (next page) details how each financing option compares across the five key considerations. For example, solar hosting is one financing option that requires little state oversight and funding as well as eliminates the up-front cost barrier. More utilities are considering offering this program in the future, which suggests increased market potential. On the other hand, this financing option has a comparatively low resident benefit because existing solar hosting programs typically offer low month-to-month bill savings. In comparison, incorporating PV into LIHEAP/WAP programs also eliminates the up-front cost impact, while directing all the benefits of the solar project to the LMI resident. The key tradeoffs here relate to the state administration considerations. In this case, the states will need to take a lead role in implementing this option and financing-related deployment. Therefore, policymakers might wish to consider these tradeoffs when designing financing programs for the LMI market.

Overall, Table 1 assesses the relative impacts of financing options in isolation, in reality, various financing options may be combined to maximize the opportunity for LMI adoption. As one example, a hypothetical LMI project could leverage direct cash incentives, tax incentives, and third-party leasing/ESA to deploy PV. In this case, the third-party developer could receive a cash incentive for constructing a LMI PV project on an eligible building from the state. The thirdparty may also be eligible for the state and federal tax incentives that could reduce the overall cost of the system. Then, the third-party could share the benefits of the project with the LMI residents as specified in the lease arrangement that accounts for the state and federal incentives. This is one of many possible financing arrangements that could be available to LMI projects. 


\section{Table 1. Comparison of State Administration and LMI Market Considerations Across Certain Financing Options}

\begin{tabular}{|c|c|c|c|c|c|}
\hline \multirow[b]{2}{*}{$\begin{array}{l}\text { Financing } \\
\text { Option }\end{array}$} & \multicolumn{2}{|c|}{$\begin{array}{l}\text { State Administration } \\
\text { Considerations }\end{array}$} & \multicolumn{3}{|c|}{ LMI Market Considerations } \\
\hline & $\begin{array}{c}\text { Ease of } \\
\text { Implementation }\end{array}$ & $\begin{array}{l}\text { Potential } \\
\text { for External } \\
\text { Investment }\end{array}$ & $\begin{array}{l}\text { Up-Front Cost } \\
\text { Impact }\end{array}$ & $\begin{array}{l}\text { Resident } \\
\text { Benefit }\end{array}$ & $\begin{array}{l}\text { Market } \\
\text { Potential }\end{array}$ \\
\hline $\begin{array}{l}\text { Bulk } \\
\text { Purchasing }\end{array}$ & & & & & \\
\hline $\begin{array}{l}\text { Capital } \\
\text { Refinancing }\end{array}$ & & & & & \\
\hline Crowdfunding & & & & & \\
\hline $\begin{array}{l}\text { Direct Cash } \\
\text { Incentives }\end{array}$ & & & & & \\
\hline Solar Hosting & & & & & \\
\hline $\begin{array}{l}\text { Low-interest } \\
\text { Loans }\end{array}$ & & & & & \\
\hline LIHEAP/WAP & & & & & \\
\hline Net Metering & & & & & \\
\hline $\begin{array}{l}\text { On-bill } \\
\text { Financing }\end{array}$ & & & & & \\
\hline PACE & & & & & \\
\hline $\begin{array}{l}\text { Production } \\
\text { Incentives }\end{array}$ & & & & & \\
\hline Tax Incentives & & & & & \\
\hline $\begin{array}{l}\text { Third-party } \\
\text { Leasing/ESA }\end{array}$ & & & & & \\
\hline $\begin{array}{l}\text { 'External investm } \\
\text { government, loc } \\
\text { ' Low-Income Ho }\end{array}$ & $\begin{array}{l}\text { may come from a varie } \\
\text { overnments, philanthro } \\
\text { nergy Assistance Progr }\end{array}$ & $\begin{array}{l}\text { f actors such as th } \\
\text { s, or the private se } \\
\text { Weatherization A }\end{array}$ & $\begin{array}{l}\text { federal } \\
\text { or. } \\
\text { istance P }\end{array}$ & 4 & $\overrightarrow{\mathrm{gh}}$ \\
\hline
\end{tabular}




\section{Considerations for Federally Supported Housing}

Millions of LMI households receive federal rental assistance or other federal support for housing (White 2012; HUD 2017c). Typically, federal support for low-income housing comes from the HUD's slate of rental assistance programs or the Low-Income Housing Tax Credit (LIHTC). ${ }^{9}$ These customers may be able to take advantage of the benefits of solar and there are a variety of examples of HUD-assisted housing deploying solar on behalf of residents (HUD 2017j). Even so, there can be details about the structure and administration of existing subsidies that can affect the ability of customers receiving rental assistance to use certain financing options. For example, the method of calculating utility allowance and metering constraints impact the way residents can benefit from on-site PV and community solar. This section discusses the scope of the federal assistance and the implications that rental assistance programs can have for the deployment of PV for LMI residents. State policymakers may wish to consider these issues when developing financing policies that incorporate federally-assisted housing.

\subsection{HUD-Subsidized Housing}

To reduce the cost burden of rent and utilities for certain LMI tenants, HUD offers several rental assistance programs including public housing, project-based rental assistance, and tenant-based rental assistance (HUD 2017a). The type of rental assistance may impact how an LMI resident can access solar and receive utility bill credits for its production. For LMI residents to participate in on-site projects the housing provider and in some cases HUD would have to approve the project. Securing these approvals and managing projects can be challenging. Another key issue for solar access and bill crediting is the metering arrangement.

For individually metered buildings, where LMI residents pay for the electricity they use, residents may be able to pursue community solar without any direct participation by the housing provider. If the building is master metered, where tenants pay utilities based on a predetermined method for allocating costs (rather than actual electricity consumption), the housing provider would have to be involved in the transaction. As a result, it may be easiest to target community solar programs to LMI residents that live in individually metered housing.

Though LMI residents may have access to solar, they may not benefit from solar bill credits. Rather, the beneficiary of these bill credits depends on how HUD and public housing authorities establish utility allowances for residents. There are three utility allowance methodologies that are used across HUD housing including asset-based, community-based, and site-specific. In the asset-based methodology, utility costs are determined through an analysis of costs across a sample of similar properties. Somewhat similarly the community-based methodology establishes utility allowances based on the typical cost of utilities for similar houses in the same locality. ${ }^{10}$ In both of these cases, the LMI resident is likely to receive some or all of the benefit of the solar bill credit. In contrast, when a housing provider uses the site-specific methodology, annual utility costs are typically calculated based on a survey of actual tenant utility bills. In this case, the solar bill credit would result in a lower utility allowance from HUD and increased tenant rent. ${ }^{11}$

\footnotetext{
${ }^{9}$ The U.S. Department of Agriculture (n.d.) also provides support for single-family and multi-family housing in rural areas.

${ }^{10} \mathrm{https://www.gpo.gov/fdsys/pkg/CFR-2002-title24-vol4/pdf/CFR-2002-title24-vol4-sec982-517.pdf.}$

11 This occurs because HUD requires LMI residents pay a combined $30 \%$ of their income on rent and utilities.
} 
Therefore, HUD would receive most or all the benefit from solar deployment, and residents would not.

The type of HUD-assisted housing has important implications for how rent and utility allowances are set, which can have different implications for LMI solar access. This section describes all three programs and clarifies the unique challenges faced by LMI residents interested in adopting PV.

\subsubsection{Public Housing}

HUD's public housing program is the oldest of the three, where HUD funds local housing authorities to offer affordable rental units to low-income tenants (HUD 2017c). In 2010, 1.2 million households resided in public housing, which represented 23\% of all HUD-assisted housing (HUD 2017c; White 2012). Public housing ranges from single-family homes in scattered housing arrangements (i.e., housing is distributed geographically) to high-rise multifamily buildings.

Public housing can have three key challenges for solar. First, any on-site PV project needs to be approved by the housing authority and HUD, which adds administrative complexity to the transaction (HUD, 2017d). Second, about half of public housing is master metered, in which case the housing authority would need to approve a resident's participation in a community solar program and administer bill credits back to the tenant, which may be problematic. Finally, public housing providers can adopt either a site-specific or asset-based utility allowance methodology to determine utility costs. If the provider uses the site-specific approach residents may not benefit from either rooftop PV or community solar bill credits. Though these challenges are not consistent across all public housing, they can represent significant barriers for deploying PV. As a result, states may wish to survey the landscape of public housing in their state prior to designing policies to serve these residents.

\subsubsection{Project-Based Rental Assistance}

HUD's project-based rental assistance program contracts with housing developers/owners to subsidize housing costs for LMI tenants (HUD 2017e). Though HUD no longer finances new projects as a part of the program, it does renew existing contracts (HUD 2017e). As is the case for public housing, there are no specific housing-type requirements and so housing varies. In 2010 , this rental assistance program accounted for 30\% of HUD-assisted housing or 1.6 million households (White 2012).

While most tenants in project-based housing pay their own utility bills, a key challenge is that providers must adopt a site-specific utility allowance methodology. As a result, LMI residents are not likely to benefit from rooftop PV or community solar. The one possible exception to this outcome is when the solar credit is determined to be an economic payment to the tenant and, pursuant to HUD's guidance, is treated as tenant income and not a utility bill reduction. In these 
cases, the LMI resident can retain about $70 \%$ of the bill credit. ${ }^{12}$ Even so, this housing type is the most challenging for passing bill credits from solar generation on to LMI tenants directly. ${ }^{13}$

\subsubsection{Tenant-Based Rental Assistance}

Tenant-based rental assistance, also known as the Section 8 Housing Choice Voucher Program is the third and largest HUD program, accounting for 46\% of all HUD units or about 2.4 million households (White 2012). In this program a tenant is given a subsidy, or voucher, to move into a market-based rent apartment of their choice.

Overall, LMI residents receiving tenant-based rental assistance may have limited access to onsite projects, but these residents could be well positioned for community solar. This is because over $90 \%$ of tenants pay their own utilities (White 2012). In addition, utility allowances are based on the community-based methodology, so tenants are likely to receive the full benefit provided by the bill credit. Therefore, serving these residents with community solar may be an attractive option.

\subsection{LIHTC-Supported Housing}

In addition to these HUD programs, there is also a substantial amount of low-income housing that is privately owned, as a result of LIHTC. This credit was enacted via the Tax Reform Act of $1986^{14}$ and nearly three million LIHTC-related housing units have since been constructed by private companies (HUD 2017f). Figure 1 shows the types of housing supported by LIHTC, which are typically large, multifamily buildings.

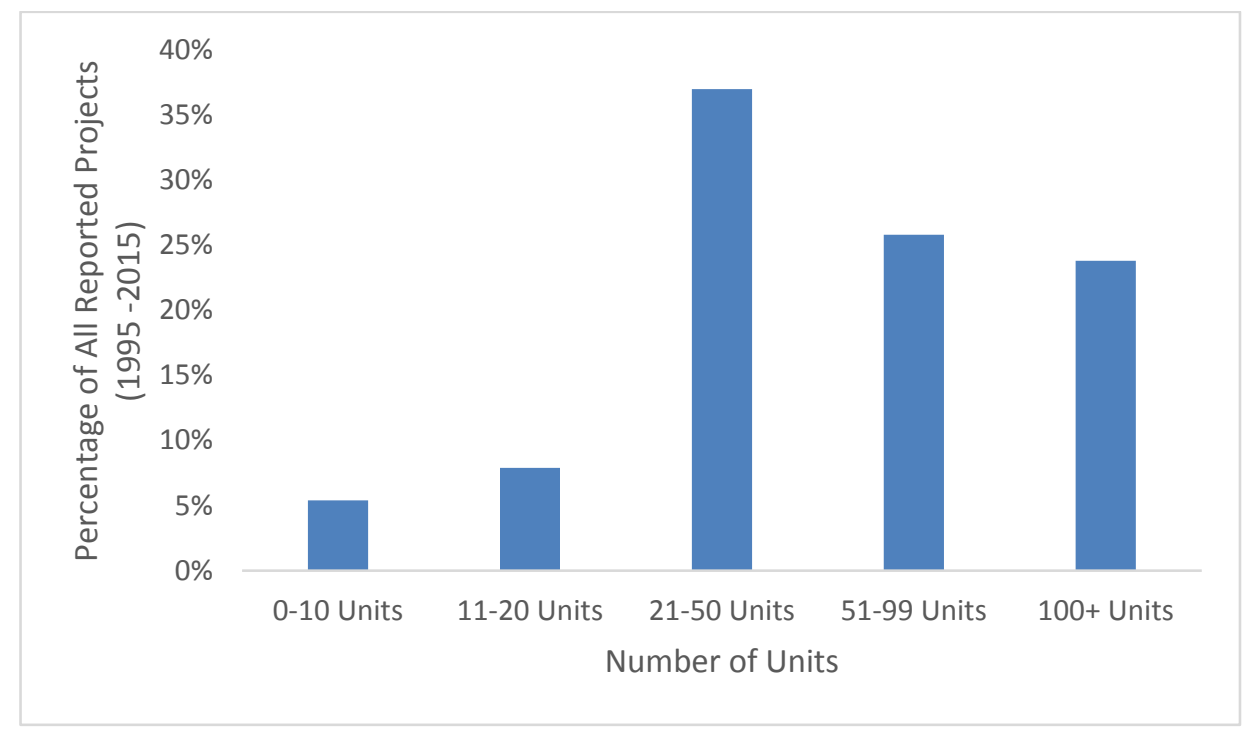

Figure 1. LIHTC housing size characteristics from 1995 to 2015. Adapted from HUD (2017f)

\footnotetext{
${ }^{12}$ For more information on how benefits might be distributed see more information on how benefits are distributed see Multifamily Housing Notice 2015-04 here: https:/www.hud.gov/sites/documents/15-04HSGN.PDF.

${ }^{13}$ Interviewees confirmed that these same challenges are likely to impact LMI residents that receive US Department of Agriculture housing assistance as well.

${ }^{14}$ See "26 U.S. Code $§ 42$ - Low-income housing credit" at https://www.law.cornell.edu/uscode/text/26/42.
} 
The design and implementation of this tax credit has some implications for solar deployment. Most importantly, this housing is not regulated by HUD. Therefore, private developers do not need to seek HUD approval for on-site PV projects. Instead, U.S. Department of Treasury and Internal Revenue Service regulations apply.

Residents in LIHTC housing that pay their own utility bills may also be able to pursue community solar, without seeking approval from their landlord. As is the case for HUD-assisted housing, how utility allowances are established can affect the benefits LMI residents might receive. Though LIHTC properties can adopt a variety of methodologies, most use PHA utility allowance schedules, which use a community-based methodology to estimate utility costs. Therefore, LMI residents would likely receive the full benefit of participation. In other cases, where alternative utility allowance methodologies are used, state regulation applies. Therefore, a review of a state's LIHTC regulations may be appropriate to clarify how solar benefits might be distributed in certain cases.

In 2016, the IRS published final regulations that address on-site PV projects. These regulations stipulate how LIHTC projects can serve individually metered LMI customers with renewable energy. Most importantly, these renewable projects do not need to be factored into the maximum rent for residents. In addition, the regulations specify that the cost of renewable electricity must be lower than what a utility would offer (U.S. Department of Treasury and Internal Revenue Service 2016). Overall, the regulations for LIHTC housing ensure that the building manager and the residents may benefit from on-site PV. ${ }^{15}$

\subsection{Summary of Subsidized Housing Financing Considerations}

Many LMI residents across the states live in federally-assisted housing and state policymakers might wish to design financing options that can be used to benefit these residents. The key issues with serving this market center on approval requirements and how solar benefits are distributed.

Relevant public and private landlords would be required to approve certain on-site projects and in master metered settings resident participation in community solar. In cases where LMI residents pay their own utility bills, they may be able to pursue community solar, without approval. Whether residents benefit from participation is dependent on the utility allowance methodology used for their housing type. Residents are likely to receive the full benefits of participation in voucher housing and LIHTC properties, and may receive little or no benefit if they reside in certain public housing or project-based rental assistance housing.

Overall, a tenant's unique federal assistance context will influence their opportunity for pursuing solar and the benefits they may receive. Moreover, federally assisted tenants are likely to live in a range of different housing types, not just multi-family. As a result, policymakers may want to understand what federal housing arrangements are most common in their state, when considering financing options to support LMI deployment across the housing types outlined in Section 4.

\footnotetext{
${ }^{15}$ Deploying on-site PV may be easiest during new construction, where the PV project can be included in a broad financing package. After construction, it can be more difficult to secure capital for PV.
} 


\section{Top Financing Options by Housing Type}

After accounting for the impact of federal assistance, the type of financing that may be most appropriate for a specific LMI project, is affected by the housing type and ownership status. The goal of this section is to explore the top financing structures that can best serve owners or renters in single-family, multifamily, and manufactured housing. The financing options discussed below for each housing type were selected based on their applicability and the unique challenges faced by LMI residents in each housing type.

\subsection{Single-Family Homes}

Within the single-family housing market there are two general types: detached and attached. Detached homes are located on an individual lot and do not share a wall with other units. In contrast, attached homes share at least one wall with an adjacent unit. The focus of this section is single-family detached homes, which accounted for $91 \%$ of the single-family housing market in 2015 (EIA 2017). Residents in attached homes will face similar challenges to those in multifamily housing, as discussed in Section 4.2.

For residents in single-family detached homes, the key driver for both solar procurement and applicable financing options is the resident's homeownership status

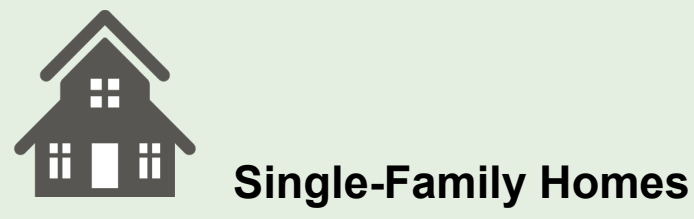

- Homeownership status is the key factor for determining PV procurement and financing options for LMI residents.

- Homeowners have access to both on-site and off-site PV, while tenants may be limited to offsite PV.

- Policymakers interested in financing on-site PV for homeowners might consider:
- LIHEAP/WAP
- Direct cash incentives
- On-bill financing
- Loans
- Third-party leasing/ESA.

- Policymakers interested in financing off-site PV for homeowners and tenants should see Section 4.4 .

because homeowners have the

authority to make decisions about procuring on-site or off-site solar, whereas tenants may need to seek landlord approval; therefore, this section is divided into two parts. The first discusses the financing options state policymakers might consider for single-family owner-occupied homes, and the second part discusses the options for renters.

\subsubsection{Financing Options for LMI Single Family Owner-occupied Homes}

For LMI residents in owner-occupied single-family homes, there are several financing options states could adopt that hold the most promise for increasing on-site solar adoption. This section discusses the advantages and disadvantages of the top financing options for on-site PV based on the LMI customer and state perspective (Table 2 compares these financing structures). The options are generally listed in order of potential to be most effective from the perspective of the customer and the state, although in some cases, there may be no appreciable difference among options. It is also possible that a single-family homeowner would wish to participate in an offsite community solar project, particularly if a rooftop system is not viable. Community solar 
financing options are covered separately in Section 4.4, given the financing options are common across renters and homeowners in multiple housing types.

LIHEAP/WAP is an attractive option for certain eligible LMI homeowners because it can reduce or eliminate the up-front cost of on-site PV. Once the PV system is installed, the resident can benefit from the electricity savings from the system. As of this writing, Colorado is the only state to use WAP and LIHEAP funding for the deployment rooftop PV, which may serve as a model for others. This approach does have some drawbacks from the perspective of an LMI resident. There are long waitlists to receive a weatherization and states often prioritize the lowest income residents for these programs. Thus, many LMI residents with more moderate incomes may not be able to benefit from this financing approach.

\section{Table 2. Advantages and Disadvantages of Selected On-site PV Financing Structures for Owner-Occupied Single-family Homes}

\begin{tabular}{|c|c|c|}
\hline $\begin{array}{l}\text { Financing } \\
\text { Option }\end{array}$ & Advantages & Disadvantages \\
\hline LIHEAP/WAP & $\begin{array}{l}\text { Eliminates the up-front cost to } \\
\text { LMI resident. } \\
\text { - } \quad \text { LMI resident receives all the } \\
\text { benefit of PV adoption at no } \\
\text { cost. } \\
\text { - Some model programs are in } \\
\text { place. }\end{array}$ & $\begin{array}{l}\text { - LIHEAP/WAP relies on federal and state } \\
\text { - } \quad \text { Depding. } \\
\text { WAP, while Department of Health and Human } \\
\text { Services approval is required for LIHEAP } \\
\text { - WAP application requirements are significant. } \\
\text { - Using LIHEAP/WAP dollars requires significant } \\
\text { state implementation capacity. } \\
\text { - WAP imposes spending caps for solar systems } \\
\text { so other funds must be leveraged (utility, } \\
\text { nonprofit, state funds, and/or grants). } \\
\text { - LIHEAP/WAP funds are only available to the } \\
\text { lowest income residents. }\end{array}$ \\
\hline $\begin{array}{l}\text { Direct cash } \\
\text { incentives }\end{array}$ & $\begin{array}{l}\text { - Reduces or eliminates up-front } \\
\text { cost to LMI resident. } \\
\text { - Some model programs are in } \\
\text { place. } \\
\text { - Low and moderate-income } \\
\text { residents can benefit from this } \\
\text { program. }\end{array}$ & $\begin{array}{l}\text { - Many of these incentives do not cover the full } \\
\text { cost of the system limiting LMI access. } \\
\text { - Relatively high cost to state taxpayers. } \\
\text { - } \text { Relatively high state administration requirement } \\
\text { - May require legislature approval. }\end{array}$ \\
\hline $\begin{array}{l}\text { On-bill } \\
\text { Financing }\end{array}$ & $\begin{array}{l}\text { - Eliminates up-front cost to LMI } \\
\text { resident. } \\
\text { - Many utilities have experience } \\
\text { with this financing structure. } \\
\text { - May not require state funding. } \\
\text { - Low and moderate-income } \\
\text { residents can benefit from } \\
\text { program. }\end{array}$ & $\begin{array}{l}\text { - New programs may require legislative approval. } \\
\text { - Utilities may be reluctant to serve as lenders. } \\
\text { - } \quad \text { Programs may be capped. } \\
\text { - Loan must be repaid despite PV system } \\
\text { performance. }\end{array}$ \\
\hline Loans & $\begin{array}{l}\text { - Eliminates up-front cost to LMI } \\
\text { resident. } \\
\text { - Some model loan programs are } \\
\text { in place. }\end{array}$ & $\begin{array}{l}\text { - Low-interest loan programs may require the } \\
\text { involvement of the state. } \\
\text { - Higher cost to taxpayers than some other } \\
\text { options. }\end{array}$ \\
\hline
\end{tabular}




\begin{tabular}{|c|c|c|}
\hline $\begin{array}{c}\text { Financing } \\
\text { Option }\end{array}$ & Advantages & Disadvantages \\
\hline & $\begin{array}{l}\text { - Public partnership with private } \\
\text { lenders can increase available } \\
\text { capital. }\end{array}$ & $\begin{array}{l}\text { - } \quad \text { LMI residents must pay interest that can limit } \\
\text { benefits. } \\
\text { - } \quad \text { LMI residents may avoid loans for nonessential } \\
\text { purchases. } \\
\text { - Loan must be repaid despite PV system } \\
\text { performance. } \\
\text { Loan terms may still not be favorable enough to } \\
\text { warrant LMI participation. }\end{array}$ \\
\hline $\begin{array}{l}\text { Third-party } \\
\text { Leasing/ESA }\end{array}$ & $\begin{array}{l}\text { Reduces up-front cost to LMI } \\
\text { resident. } \\
\text { Some model lease programs } \\
\text { are in place. } \\
\text { Allows for monetizing certain } \\
\text { tax incentives that may be } \\
\text { unavailable to LMI residents. }\end{array}$ & $\begin{array}{l}\text { May require involvement of the state to foster } \\
\text { private investment. } \\
\text { LMI residents must share benefits with third- } \\
\text { party, which can reduce LMI benefit relative to } \\
\text { other options. } \\
\text { - Legislation may be necessary in certain states } \\
\text { to open this pathway. }\end{array}$ \\
\hline
\end{tabular}

From a state's perspective, integrating PV into WAP programs has some benefits and drawbacks. Namely, eligible projects that incorporate PV can leverage federal dollars. In 2017, the Department of Energy (DOE; 2017a) capped those qualifying expenses at $\$ 3,598$ per PV system. As a result, states can use that funding or combine it with state dollars to maximize deployment. On the other hand, using DOE funding requires DOE approval. At this time, the DOE must approve state WAP programs that include solar as well as the individual projects that use DOE funds. The application and approval processes can be lengthy and may require significant staff time. States that have smaller WAP programs or limited staff may not be able to complete the process and fold solar into their programs. These implementation challenges may limit the use of WAP financing for LMI rooftop PV deployment.

On the other hand, LIHEAP funding has fewer implementation barriers. For instance, states can use up to $25 \%$ of their LIHEAP funding for weatherization, and Colorado and California have received approval from the Department of Health and Human Services (HHS) to use LIHEAP funds for PV. This option comes with less cost to the state because it can rely on federal dollars to serve their LMI PV deployment goals. Nevertheless, it still requires building expertise in state LIHEAP programs that are related to PV. There are also drawbacks to LMI residents that are consistent with those outlined for WAP. For example, more moderate-income residents would also not be eligible as is the case for WAP.

Direct cash incentives can also reduce or possibly eliminate up-front investment costs; therefore, this financing approach can be attractive to LMI residents. There are a variety of these programs that have been deployed for the LMI market, including the California SASH program mentioned earlier that can cover the full cost of a system depending on an LMI resident's income. The benefit of these programs is that they can be designed to fill the gap between what an LMI customer can pay and the cost of the system. This approach can ensure that both lowand moderate-income residents can have access to rooftop PV. The challenge for the state is to identify the appropriate incentive needed. In addition, these incentive programs can come at a 
significant cost to the state and may require legislative approval prior to adoption; therefore, these programs can represent a significant implementation challenge for the state.

On-bill financing also eliminates the up-front cost barrier to the homeowner in favor of monthly payments. These payments are typically offset by the credit received from the generation of the system. This financing option can also be used effectively for both low- and moderate-income residents. Though this can result in lower electricity costs for LMI residents, residents will not receive the full benefit of PV until they have paid for the system. As a result, the impact on the customer's energy burden may be delayed.

This approach offers some benefits and drawbacks to the state in terms of administration and cost. In some states, legislative approval may be required to establish a program, which can be challenging. Outside of this requirement, utilities or other third-parties can manage the program. This structure can be attractive to states as compared to others that require more long-term state commitments. In addition, utilities or the third-parties serve as the lender, thereby limiting the cost to the state. Given utilities across 32 states currently offer these programs, implementation for LMI customers may be feasible and potentially easier in some instances than other financing options. However, the reliance on utilities, which may be reluctant to serve as lenders or make investments to ease implementation (such as updating billing systems), may limit the opportunity for LMI residents to benefit from these programs.

Loans, and in particular low interest loans, may be favorable financing options because they reduce the up-front cost of the system. Some states, such as Massachusetts and Connecticut, offer low-interest loans; Connecticut's Smart-E loan program offers a no money down option (Connecticut Green Bank 2017a). This approach allows LMI residents to begin receiving solar benefits before paying for the system.

The drawbacks from a LMI resident perspective are threefold. One, private lenders may be unwilling to offer loans to LMI residents with lower credit scores. Two, if an LMI resident gets approved for a loan, they may not accept it because they cannot afford to pay the interest or do not want to assume the risk of nonpayment penalties. Third, LMI customers must pay interest on the loans which can offset some of the benefits they receive from PV. Given these concerns, loan programs may be better suited to serve moderate income families that may have more disposable income and less risk of default.

The design of the Massachusetts and Connecticut programs offer some perspective on the tradeoffs that states need to consider regarding the implementation and cost of loan programs. In Connecticut, the state's Green Bank, a governmental entity, administers the program (Connecticut Green Bank 2017b). In comparison, Massachusetts' program is a partnership between state and private lenders. Either approach may be helpful because it may result in more available capital and opportunity for LMI PV adoption (Executive Office of Energy and Environmental Affairs 2017a). Regardless, the state takes an active role in administering and funding both programs, which requires time and resources that other states may not have. These factors may impact whether a state is interested in pursuing this financing approach.

Third-party leasing/ESA financing can reduce or eliminate up-front investment in favor of monthly payments to a third-party solar owner. For single family homeowners, third-party 
contracts are often in the form of a power purchase agreement, where the third-party owns and maintains the PV system and the LMI resident benefits from a portion of the generation. Importantly, the third-party can often monetize available tax credits that LMI residents may not. These benefits can then be integrated into the power purchase agreement, thereby increasing the potential savings for an LMI resident. There are a few key disadvantages to this approach. First, how these benefits are shared is decided within the contract terms of the leasing agreement that may result in fewer benefits accruing to the resident as compared to some other options. Second, there are only a few instances where third-party leasing has been successfully deployed in the LMI market, including PosiGen's partnership with the Connecticut Green Bank (Connecticut Green Bank 2017a; Connecticut Green Bank. 2017c). ${ }^{16}$ This results in part from the low credit scores that LMI resident often have, which can discourage private developers.

There may be an important role for the state to support third-party leasing in the LMI market by subsidizing private developer contracts. This increases the costs of this option as compared to others, while also increasing state implementation requirements. In addition, third-party leasing is prohibited in some states. In these states, legislation may be required to address this issue, while securing approval for power purchase agreements in any state may prove challenging.

\subsubsection{Financing Options for Single-Family Home LMI Tenants}

The key challenge for single-family home renters is that they lack the control to make decisions regarding solar installations on their home or lot. As a result, the landlord has to be involved to approve on-site projects. This does not preclude the resident from benefiting from solar, rather the tenant and landlord can work together to leverage certain financing options. For example, an interested tenant and landlord could leverage LIHEAP/WAP funds to cover the cost of a system. In the case of WAP funds, the benefits would have to be passed to the eligible tenant and not the landlord. Other financing pathways, such as third-party leasing, could be used as well, but it is unclear how benefits would be shared between the LMI tenant and the landlord. State policymakers could play a role in clarifying these benefits, particularly if the state takes an active role in the third-party financing program. Nevertheless, it may be more difficult for state policymakers to foster on-site PV deployment for single family home renters, compared to homeowners.

In comparison, it may be easier for state policymakers to support access to community solar for LMI tenants, as opposed to rooftop PV. Tenants that pay their own utility bills directly are able to participate in community solar without a landlord's approval. If the landlord pays the utilities, the landlord would still need to be involved to participate in a community solar project. Though LMI tenants may more easily participate in community solar, they still face financing obstacles. Section 4.4 discusses these financing obstacles as well as the top financing options to foster LMI adoption of community solar.

Ultimately, there are some pathways to serve single-family home renters. From the state perspective, designing on-site PV programs that address the split incentive issue between landlords and renters may require significant state investment to encourage landlords and tenants to work together. In comparison, states may have more success in serving the LMI renter market

\footnotetext{
${ }^{16}$ GRID Alternatives in partnership with Sunrun has entered into a third-party leasing arrangement to offer systems
} in relation to California's SASH program (Sunrun 2017). 
by fostering access to off-site PV, especially for those residents that pay their own utility bills. Though it may be easier to design community solar programs than on-site programs, state involvement in community solar also comes with challenges also described in Section 4.4.

\subsection{Multifamily Housing}

There are a variety of multifamily housing types ranging from a twounit duplex, to a large 100-unit highrise apartment or condominium complex. In multifamily housing, the key issues for solar deployment are less associated with ownership type than in the case of single-family and manufactured housing. LMI residents that might own a unit in a multifamily building likely do not own or control portions of the roof or related property. Rather, a landlord, building manager, or possibly a homeowner association has the authority over the roof and other common areas. As a result, LMI homeowners would have to work through these entities to deploy onsite PV just as tenants would. ${ }^{17}$

\section{Multifamily Housing}

- Multifamily housing providers play a key role in approving on-site PV projects, regardless of resident's homeownership status.

- Policymakers might consider a range of financing options to encourage housing providers to adopt on-site PV, including:

- Capital refinancing

- Third-party leasing/ESA

- LIHEAP/WAP

○ On-bill financing

- PACE.

- Policymakers interested in financing off-site PV for homeowners and tenants should see Section 4.4 .

Ultimately, the key challenges for on-site PV deployment in multi-family housing relate to project approval processes and the distribution of the benefits of the PV system output. First, a building manager would be required to approve an on-site PV project. Depending on the housing arrangement, the project may also require approval from homeowners within the building as well as HUD. HUD approval is required for any multifamily building that receives either public housing or project-based rental assistance. This adds another layer of complexity to deploying PV for LMI residents in multifamily buildings that is not typically present in the single-family context.

The second key challenge is distributing PV benefits. Building owners may have the capital to invest in on-site PV projects on LMI housing. They may also be interested in deploying PV to serve their own utility expenses related to common areas without distributing benefits to residents. Thus, the key issue for states that seek to ensure LMI residents benefit from on-site PV in multifamily housing is to design programs such that these benefits are shared.

In a case where landlords are interested or mandated to share benefits with residents, the metering of the building can cause challenges. A master metered building has one meter to track

\footnotetext{
${ }^{17}$ One key distinction is that a homeowner could have a higher benefit from on-site PV, given the installation may increase the value of the home if they choose to sell. Tenants that move would not be able to benefit from this installation in the same way.
} 
electricity consumption for the entire building. This can make it challenging to distribute benefits or encourage individual tenants to manage electricity use. If the building is individually metered, tenants are responsible for their own individual utility bills. In this arrangement it may be easier to distribute benefits between LMI residents and the building provider.

Overall, there is a significant role for the multifamily housing provider to adopt on-site PV and there are a variety of financing options for these entities. In some cases, these programs have been fostered by states to encourage PV deployment that benefits LMI residents. Thus, this section discusses the financing options that states could adopt or emphasize to encourage providers to adopt PV. We then turn to a discussion of the options states could adopt for multifamily housing residents to participate in off-site community solar projects.

\subsubsection{Financing Options for Multifamily Housing Providers}

In comparison to single-family homeowners, multifamily housing providers have different types of financing options available to them that could be used to install PV. This section discusses five of the top financing options for multifamily and affordable housing authorities to finance onsite solar projects and each is summarized in Table 3. Multifamily housing providers may also be eligible for off-site community solar and these options are described in Section 4.4.

\section{Table 3. Advantages and Disadvantages of Selected Financing Structures for Multifamily Providers}

\begin{tabular}{|c|c|c|}
\hline $\begin{array}{c}\text { Financing } \\
\text { Option }\end{array}$ & Advantages & Disadvantages \\
\hline $\begin{array}{l}\text { Capital } \\
\text { Refinancing }\end{array}$ & $\begin{array}{l}\text { - Eliminates up-front cost to } \\
\text { landlord. } \\
\text { Does not require state } \\
\text { funding. } \\
\text { Does not require legislative } \\
\text { activity. }\end{array}$ & $\begin{array}{l}\text { - No clear mechanism to pass PV benefits to LMI } \\
\text { residents. } \\
\text { - } \quad \text { Relies on voluntary action from building owners. } \\
\text { - Solar may have to compete with other possible } \\
\text { projects. } \\
\text { Opportunity may be greatest for larger buildings or } \\
\text { landlords with multiple buildings than those with } \\
\text { smaller holdings. }\end{array}$ \\
\hline $\begin{array}{l}\text { Third-party } \\
\text { leasing/ESA }\end{array}$ & $\begin{array}{l}\text { Reduces or eliminates up- } \\
\text { front cost to landlord. } \\
\text { Third-party leasing is } \\
\text { common in the market. } \\
\text { - May not require state } \\
\text { funding. } \\
\text { More opportunity to } \\
\text { leverage tax credits. }\end{array}$ & $\begin{array}{l}\text { - No clear mechanism to pass PV benefits to LMI } \\
\text { residents outside of certain HUD-supported } \\
\text { housing. } \\
\text { - } \quad \text { Concerns about third-party contract terms. } \\
\text { - Contract administration and benefit distribution can } \\
\text { be costly. } \\
\text { - May require HUD approval. }\end{array}$ \\
\hline
\end{tabular}




\begin{tabular}{|c|c|c|}
\hline $\begin{array}{c}\text { Financing } \\
\text { Option }\end{array}$ & Advantages & Disadvantages \\
\hline LIHEAP/WAP & $\begin{array}{l}\text { Eliminates the up-front cost } \\
\text { to resident. } \\
\text { - LMI residents receive some } \\
\text { benefit from PV project. }\end{array}$ & $\begin{array}{l}\text { - } \quad \text { Relies on federal and state funding. } \\
\text { DOE approval is required for WAP funds, while } \\
\text { HHS approval is required for LIHEAP funds } \\
\text { - } \quad \text { WAP application requirements are significant. } \\
\text { - } \quad \text { Limited in-the-field examples. } \\
\text { - Housing provider must commit capital to WAP- } \\
\text { related projects. } \\
\text { Providers may wish to pursue other more favorable } \\
\text { financing options. }\end{array}$ \\
\hline On-bill Financing & $\begin{array}{l}\text { Eliminates up-front cost to } \\
\text { landlord. } \\
\text { Many utilities have } \\
\text { experience with this } \\
\text { financing structure. } \\
\text { - May not require state } \\
\text { funding. }\end{array}$ & $\begin{array}{l}\text { - } \quad \text { No clear mechanism to pass PV benefits to LMI } \\
\text { - } \quad \text { Utility may not be comfortable serving a lender role. } \\
\text { - } \quad \text { New programs may require legislative approval. } \\
\text { - } \quad \text { Programs may be capped. } \\
\text { - } \quad \text { Loan must be repaid despite PV system } \\
\text { performance. }\end{array}$ \\
\hline PACE & $\begin{array}{l}\text { Reduces or eliminates up- } \\
\text { front cost to landlord. } \\
\text { Some success stories exist } \\
\text { and might serve as models. }\end{array}$ & $\begin{array}{l}\text { - No clear mechanism to pass PV benefits to LMI } \\
\text { residents, outside of certain HUD-supported } \\
\text { housing. } \\
\text { - } \quad \text { Approval and contract administration processes } \\
\text { take time and resources. } \\
\text { - } \quad \text { Possibly unfavorable financing terms. } \\
\text { - } \quad \text { May require state funding support. } \\
\text { - } \quad \text { New legislation or policy to allow multifamily } \\
\text { housing participation may be necessary. }\end{array}$ \\
\hline
\end{tabular}

Capital refinancing is one option for building owners to fold a solar installation into a portfolio of building renovations through refinancing. Owners of large buildings or multiple buildings can refinance to generate capital for building improvements such as a roof replacement or energy projects including solar (Clean Energy Advisory Council 2017). Incorporating solar into a refinancing deal would significantly reduce the up-front cost and requires no funding or action from the state. In addition, including solar in capital refinancing may result in a scenario where year one benefits might be sufficiently high to cover the yearly capital payment associated with the solar project.

There are some drawbacks to relying on capital refinancing to achieve a state's LMI PV goals. The most significant one is that the housing provider may not have an incentive to share PV benefits with LMI residents. There are some steps states could take to address this issue. For example, the Connecticut Green Bank offers a catalyst financing program that is meant to fill funding gaps for energy projects for multifamily housing (Connecticut Green Bank 2017c). Similar programs could support the inclusion of PV in these projects, while requiring that some of the benefits of that project be distributed to LMI residents. Outside of the benefit distribution concern, there are two other key issues that may limit the market potential for this approach. Housing providers may not be interested or willing to refinance frequently and building owners may have a long list of deferred maintenance projects that solar would need to compete with for 
limited funds. ${ }^{18}$ Addressing these issues may prove challenging for states relative to other options, which may limit the market potential for PV from this financing approach.

Third-party leasing/ESA is another attractive financing tool for multifamily housing providers. This financing structure allows the provider to outsource installation and maintenance of the system, while receiving the benefits. In this arrangement, a provider can sign a contract with a third-party that incorporates on-site PV and possibly other energy efficiency measures, as is typical in an ESA. Once installed, the savings associated with these projects are shared between the building manager and the third-party. The third-party is then in charge of operating and maintaining the system and the building manager can obtain or distribute the benefits of the project to residents. Third-party financing is helpful because it reduces the up-front cost for the system and the effort required by the housing provider to install and maintain a PV system. Third-party leasing through power purchase agreements and ESAs are widely used in the multifamily housing sector and require little state support because private partners are willing to work with landlords.

Leveraging either third-party option in this segment is also attractive to landlords because these partners may be able to utilize tax credits. Some multi-family housing providers may have limited tax liabilities or be run by public agencies or nonprofits. If this is the case, the third-party might be able to leverage available tax credits for the solar installation and pass some of that benefit to the building owner and LMI residents. For example, the Housing Authority of the City and County of Denver partnered with third parties and successfully signed an agreement to install 2.5 MW of rooftop PV across 385 buildings. ${ }^{19}$

Though this option offers some significant benefits to the state in terms of ease of implementation and cost, there are drawbacks associated with market potential of this approach and the benefits tenants might receive. These issues may be important to states as they consider the impact this approach would have on their deployment goals.

Not all building providers are able or interested in using third-party financing to deploy PV. Approving contracts takes time, resources, and expertise that the provider may not have. Though future savings could be used to offset these costs, they still require an up-front investment from the building provider. In addition, certain larger buildings with greater savings potential may attract the interest of third-party providers, while smaller buildings may not. It might be possible for a multi-family housing provider that manages several properties to aggregate those facilities into a more attractive package for private partners, but this may take additional time and resources. Finally, if the multi-family housing provider received HUD public housing or projectbased rental assistance, these contracts must also be approved by HUD which can take time and resources (HUD 2017g). As a result, the availability of this option alone may not spur significant

\footnotetext{
${ }^{18}$ It is possible that PV savings could be used to complete more improvements, which may make landlords more interested in this approach.

${ }^{19}$ For more information on this project, see "PHA Leverages Power Purchase Agreement for Jurisdiction-wide Scattered Site Solar Installations" at https://www.hudexchange.info/onecpd/assets/File/Renewables-in-Practice-Case-Study-Denver-HousingAuthority.pdf.
} 
deployment, because providers may not have the time and resources to commit to a third-party agreement.

In addition to the potential lack of interest from multifamily providers, residents may not actually benefit from certain third-party owned PV projects. Private landlords may enter into third-party financing contracts and use the savings to lower their own operation costs. This is of particular interest to state policymakers, given that LMI residents may not benefit from PV deployment in these contexts. This is not the case for HUD-assisted housing where HUD approval is contingent on multifamily building providers sharing the benefits with LMI residents in some form. State policymakers may wish to consider ways to encourage HUD-assisted housing to participate in ESAs, to meet their LMI solar deployment goals. Encouraging private landlords to share benefits with LMI residents may require more effort and potentially some state funding.

LIHEAP/WAP funding may be used for certain solar projects in multifamily buildings. These funding streams are attractive because they require no up-front cost or long-term investment from residents. LIHEAP or WAP funding can also be used for other building upgrades, such as health and safety improvements, that can address some building condition issues that might preclude solar investment. However, as of this writing, there are no examples of using WAP or LIHEAP funds for installing solar on multifamily housing, though some states are considering it.

One key factor limiting the use of LIHEAP or WAP funds is the fact that the state needs to incorporate solar into its LIHEAP or WAP program before projects can use these funds. The same approval requirements and associated challenges as outlined in the single-family market apply and are thus not reiterated here. In summary, unlocking this financing approach requires significant time and investment from states, which may limit the attractiveness of this option.

Even if a state approved the use of WAP funds, other factors may influence the use of this funding stream. To be eligible for WAP funds, at least $66 \%$ of the residents in a building must meet WAP income eligibility requirements (DOE 2017b). Therefore, many facilities with more mixed income residents could not use WAP funds. Another factor that may limit deployment is the requirement that multifamily housing providers contribute some of their own capital to WAP-related projects, which may be challenging for some providers. ${ }^{20}$ Instead, building providers may opt for other financing options such as an ESA where the provider may not have to provide up-front funding. Landlords may also be interested in this approach because they may be able to capture the full benefit of the project, while WAP requires building providers to share benefits with tenants. As a result, state approval of the use of WAP funds alone may not result in significant deployment.

On-bill Financing may be available to some multi-family providers in those state programs that allow it, such as California and Illinois (NCSL 2015). This financing structure is appealing because it reduces the up-front cost of the PV system and allows the provider to pay for a system over time. Given that utilities across 32 states have experience with these programs, implementation may be easier in some instances than other options. Moreover, utilities may be more willing to serve as a lender to multifamily building providers who have less risk of

${ }^{20}$ LIHEAP does not have similar requirements, though some states have adopted WAP's regulations for their LIHEAP weatherization programs. 
defaulting on payments than single-family homeowners. Again, the key issue is whether benefits are shared between the building manager and residents. If states want to pursue this pathway, they may want to consider establishing policies that ensure benefits are shared. Outside of this issue, developing new on-bill programs, or allowing multi-family provider participation in existing programs may require legislative approval. Finally, program caps may also limit the ability of multifamily housing providers to access this financing option.

PACE financing is also available for multifamily housing providers in at least three states and the District of Columbia. The Connecticut Green Bank (2016) includes multifamily housing entities in their commercial PACE program, California launched a multifamily affordable housing PACE pilot program in 2015 (HUD 2017h), and a few projects have been completed in Michigan and the District of Columbia (Sanchez, Henry, and Ryan 2016). This financing structure also reduces the up-front cost of the system, which can be attractive for those housing providers with limited capital. In addition, the successful projects in Michigan and the District of Columbia may serve as models for other state programs.

There are some key challenges with PACE financing, including the potentially higher financial terms for PACE loans that can reduce the benefits to the landlord and potentially residents. Therefore, even if other states adopted legislation allowing PACE financing, it is unclear that multifamily providers would be interested in this option. Though PACE programs in theory require less investment from the state, given multifamily providers would pay for the system via their property tax bills, the Connecticut and California programs both leveraged state funding. As a result, states considering this option may need to evaluate available funding streams to support the program while also seeking legislation to allow multifamily PACE programs. In addition, it is unclear how LMI residents might benefit from PACE-financed PV; if states subsidize the programs, they may have more leverage to require some distribution of benefits to residents. Finally, if a facility receives support from HUD, a PACE loan requires HUD approval (see HUD 2015 for guidance on how multifamily housing providers can receive this approval). Even so, carrying out this approval process and others associated with signing a PACE agreement can take time and resources that a multifamily housing provider may not have.

\subsubsection{Financing Options for Multifamily LMI Residents}

Ultimately, LMI residents of multifamily housing facilities might be precluded from deploying on-site solar without their landlord's involvement. It may still be possible for these residents to participate in off-site community solar, but they could face some barriers to this pathway, depending on the metering of the building.

If the tenant lives in an individually metered building, he/she may be able to participate in community solar without approval from the landlord. In this arrangement, the LMI resident would directly benefit from their solar subscription just as a homeowner or tenant would in a single-family home. However, these residents are also likely to face the same community solar financing challenges as their counterparts in single-family homes, as outlined in Section 4.4.

If the tenant lives in a master metered building, LMI residents would need the landlord to be involved to participate in community solar. This is because it can be challenging to determine the LMI customer's load and the appropriate credit for community solar. This may require the landlord to participate in the community solar project on behalf of all renters or homeowners and 
distribute benefits across residents equally. These administrative challenges may serve as a barrier to deployment in these buildings.

Multifamily buildings have an advantage in that the developer can work with one building manager and potentially secure hundreds of LMI customers to participate in a community solar program. This can be easier than trying to aggregate many disparate LMI single family homeowners to participate in community solar. For example, the Boulder Housing Authority partnered with Clean Energy Collective to provide community solar to its residents. Here, Boulder Housing Authority manages subscriptions, notifies Clean Energy Collective when customers move, and helps identify other willing participants for a 500-kilowatt solar garden (Beal et al. 2015). This approach has the potential to reduce customer acquisition costs for developers and potentially encourage them to seek more LMI participation in their projects.

In both metering arrangements, the housing provider involvement may actually be preferable to ensure LMI customer participation in community solar, by serving as an aggregator of participants. Therefore, states may wish to consider community solar and financing policies that allow for participation of the housing provider to increase PV deployment for LMI families in this housing stock.

\subsection{Manufactured Housing}

The ownership structure for manufactured homes differs from other housing types and there are three common variations. First, the resident may be the homeowner and own the land where the home is located. Second, the resident may be the homeowner but rent the lot. Third, the resident may rent the home and the lot. These different ownership structures for the home and the lot are important because they influence the opportunities that homeowners or renters have to deploy solar.

Most manufactured homes are not intended to support rooftop PV, though some new models have this capability. ${ }^{21}$ In most cases, on-site solar would have to come from a ground-mounted system. This is

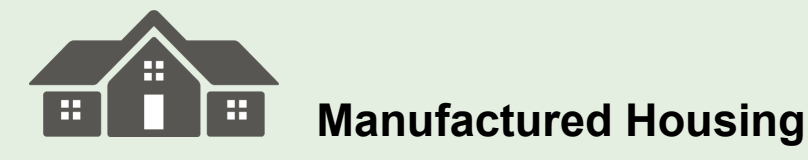

- A resident's home and land ownership status are the key factors for determining PV procurement and financing options.

- Given residents often do not own the land or the lot, it is important that the landlord participate in on-site PV projects.

- Policymakers might consider a range of financing options to encourage housing providers to adopt on-site $\mathrm{PV}$, including:
- LIHEAP/WAP
- Third-party leasing/ESA
- Direct cash incentives
- Tax incentives
- PACE.

- Policymakers interested in financing off-site PV for homeowners and tenants should see Section 4.4. where the ownership of the lot comes into play because the relevant landlord would have to approve the ground-mounted system. In a

\footnotetext{
${ }^{21}$ There are some examples of manufactured homes that are capable of supporting rooftop PV. For these facilities, LMI homeowners could deploy solar or seek approval from a landlord to do so. For example, see Clean Energy Group (2017).
} 
situation where the manufactured home can support solar, the home's roof pitch may not maximize solar capture; therefore, it still may be more cost-effective to install a ground-mounted system. In the event an on-site system is not feasible, a homeowner or tenant may still be able to participate in an off-site community solar project. This approach may also be preferable to either on-site case, given lower transaction costs and required approvals to deploy PV.

Given that it is common for a resident to live in a manufactured home community where the resident may not own the lot, the home, or both, this section first details the financing pathways states could consider to incentivize manufactured housing providers to deploy on-site solar on behalf of residents. Then, it turns to the financing options states could select to allow LMI residents in manufactured housing to deploy on- and off-site solar without action from the landlord.

\subsubsection{Financing Options for Manufactured Housing Providers}

There are examples of manufactured housing providers using existing financing options to deploy on-site solar and in some cases directly benefitting LMI residents. As a result, this section walks through some of the top financing options available to these landlords and the key considerations for state policymakers as it relates to achieving their LMI PV deployment goals.

These providers share three top financing options with multifamily housing providers: LIHEAP/WAP, PACE, and third-party leasing/ESA (see Table 5). The benefits and challenges of PACE and third-party leasing/ESA are similar to those outlined in Section 4.2, for multifamily housing providers and are not reiterated in detail here. Rather, the key issue remains that, absent state activity, there is no clear mechanism to distribute PV benefits between landlords and LMI tenants in either PACE or third-party leasing/ESA. There are some differences between how a manufactured housing landlord could use LIHEAP/WAP financing as compared to a multifamily provider. In the latter case, landlords must commit some of their own capital to the project but manufactured housing providers might not do so. These landlords may be treated similarly to other single-family home landlords, who just approve the project. Ultimately, the authors could not find an in-the-field example where LIHEAP/WAP funding was used in this setting so there is some uncertainty regarding how these providers would be treated as related to funding eligibility and whether federal WAP dollars can be used for ground-mounted systems. Federal guidance on these questions may be helpful before a state considers developing a program relating to manufactured housing in their WAP program. If the option is available, it would directly benefit the LMI customer and eliminate up-front and ongoing payments much as they do in the singlefamily owner-occupied market outlined in Section 4.1.

In comparison, manufactured housing providers may not be able to access capital refinancing or on-bill financing as multi-family housing providers can. First, manufactured housing providers may not have access to as much capital as large multifamily housing facilities do or have significant operation and maintenance costs that would justify refinancing that may preclude this option. Second, it is unclear whether manufactured housing providers qualify for on-bill financing; this would depend on the definition of eligible multifamily housing as stipulated in state and utility programs. It is possible that manufactured housing providers are excluded in these definitions. As a result, both financing options are not included in this section. Rather, this section includes two different options used in this market segment: direct cash incentives and tax incentives (see Table 6). 


\section{Table 6. Advantages and Disadvantages of Selected Financing Structures for Manufactured Housing Providers}

\begin{tabular}{|c|c|c|}
\hline $\begin{array}{l}\text { Financing } \\
\text { Option }\end{array}$ & Advantages & Disadvantages \\
\hline LIHEAP/WAP & $\begin{array}{l}\text { Eliminates the up-front cost to } \\
\text { landlord and LMI resident. } \\
\text { - LMI resident receives all the } \\
\text { benefit of PV adoption at no } \\
\text { cost. }\end{array}$ & $\begin{array}{l}\text { - } \text { Relies on federal and state funding. } \\
\text { DOE approval is required for WAP, while HHS } \\
\text { approval is required for LIHEAP funds } \\
\text { - } \quad \text { WAP application requirements are significant. } \\
\text { Requires significant state implementation } \\
\text { capacity. } \\
\text { - } \quad \text { WAP imposes spending caps for solar systems. } \\
\text { - There is uncertainty regarding how to use } \\
\text { LIHEAP/WAP funds for solar on or near } \\
\text { manufactured housing. } \\
\text { - There are no in-the-field examples. }\end{array}$ \\
\hline $\begin{array}{l}\text { Third-party } \\
\text { Leasing/ESA }\end{array}$ & $\begin{array}{l}\text { - May eliminate up-front cost to } \\
\text { landlord. } \\
\text { - Third-party leasing is common } \\
\text { in the market. } \\
\text { - May not require state funding. } \\
\text { - More opportunity to leverage } \\
\text { tax credits. }\end{array}$ & $\begin{array}{l}\text { - No clear mechanism to pass PV benefits to LMI } \\
\text { residents. } \\
\text { - Developers may not be interested in taking on risk } \\
\text { in cases of split ownership. } \\
\text { - Concerns about third-party contract terms. } \\
\text { - Contract administration and benefit distribution } \\
\text { can be costly. }\end{array}$ \\
\hline $\begin{array}{l}\text { Direct cash } \\
\text { incentives }\end{array}$ & $\begin{array}{l}\text { - Reduces up-front cost to } \\
\text { landlord and LMI resident. } \\
\text { - LMI residents may capture all } \\
\text { solar-related benefits. } \\
\text { - Vermont offers one example of } \\
\text { how this pathway can be } \\
\text { successful. }\end{array}$ & $\begin{array}{l}\text { - This can result in a high cost to the state. } \\
\text { - These incentives may not cover the whole } \\
\text { system, so private capital may need to be } \\
\text { involved. } \\
\text { - This approach may be most effective for new } \\
\text { manufactured housing as opposed to retrofitting } \\
\text { existing homes. }\end{array}$ \\
\hline Tax Incentives & $\begin{array}{l}\text { - Offsets total cost to landlord. } \\
\text { - Depending on the incentive } \\
\text { there is no cost to the state. } \\
\text { Incentive may increase the } \\
\text { economic viability of the project. }\end{array}$ & $\begin{array}{l}\text { - No clear mechanism to pass PV benefits to LMI } \\
\text { residents. } \\
\text { - May need to be coupled with other financing } \\
\text { options. } \\
\text { - Subject to tax incentive availability. }\end{array}$ \\
\hline PACE & $\begin{array}{l}\text { - Lowers or eliminates up-front } \\
\text { cost to landlord. } \\
\text { - Some success stories exist and } \\
\text { might serve as models. }\end{array}$ & $\begin{array}{l}\text { - No clear mechanism to pass PV benefits to LMI } \\
\text { residents. } \\
\text { - } \quad \text { Approval and contract administration processes } \\
\text { take time and resources. } \\
\text { - } \quad \text { Possibly unfavorable financing terms. } \\
\text { - Likely requires state funding support. } \\
\text { - New legislation or policy to allow participation } \\
\text { may be necessary. }\end{array}$ \\
\hline
\end{tabular}

Direct cash incentives have been used in at least one instance to install PV on manufactured homes: the McKnight Lane Affordable Housing Development (McKnight Lane) in Vermont. The state of Vermont partnered with a manufactured housing provider and contributed about $\$ 1.1$ million or 30\% of the capital investment for 14 new manufactured homes that incorporated solar and storage systems (Clean Energy Group 2017). The homes will produce more energy than they consume over the course of the year and reduce LMI customer utility and rent 
payments. The benefit of this approach is that it eliminates the up-front cost for LMI customers and solar benefits are passed directly to the customers through lower rent. As a result, the McKnight Lane project could serve as a framework for projects in other states. A key challenge with this approach is that it can require significant state funds and potentially legislative approval. Even with this support, the McKnight Lane project also required additional federal and private investment. Finding willing partners can take time and resources.

Tax incentives may be available to certain manufactured housing providers with significant tax liabilities, which could encourage these providers to adopt PV. Huntington Shorecliffs, a manufactured housing provider, plans to leverage the federal investment tax credit (ITC) to install a PV system on common-area roofs and carports at a development in Huntington Beach, California (CleanFund 2017). Huntington Shorecliffs has also partnered with CleanFund, to provide PACE financing for the project. The benefit of this approach is there may be no cost to the state. The challenge here is that tax incentives may need to be coupled with other financing options, as this example suggests. In addition, it is unclear how LMI tenants will benefit, if at all, from the installed system. Finally, the financial support offered by tax incentives is subject to applicable tax incentive step downs and expiration dates. For example, the federal ITC for solar is scheduled to phase down from $30 \%$ in 2017 to $10 \%$ in $2022 .{ }^{22}$ To encourage providers to deploy PV and share benefits with LMI residents, they could consider adopting their own tax incentives or providing programs designed to encourage landlords to share solar benefits with LMI residents in parallel to existing credits.

\subsubsection{Financing Options for Manufactured Housing LMI Residents}

In the event an LMI homeowner also owns the lot, he/she may have the ability to deploy on-site solar without a landlord's approval. If this is the case, these homeowners might have access to the same financing options outlined in Section 4.1 for single-family homeowners with two key caveats for states. The first relates to LIHEAP/WAP. Though rooftop systems have been installed using WAP funding in Colorado, as of this writing neither source of funding has been used to deploy ground-mounted solar for manufactured housing. As a result, there is no existing guidance or examples that can be used as models for interested states. In addition, older manufactured housing may not be able to support rooftop PV, so ground mounted projects may be necessary. This could add a layer of implementation complexity to state programs, while also limiting the potential market because many homeowners may not own the lot.

Second, the individual could work with the landlord to install a ground-mounted system if the LMI resident rents the manufactured home, the lot, or both. This would spur the same kind of challenges as outlined in Section 4.2.2 for single-family renters. Given the uncertainties and complexities associated with serving LMI homeowners in manufactured housing, these residents may more easily be served by community solar. The top financing options for this pathway are described below in Section 4.4.

\footnotetext{
${ }^{22}$ See "Business Energy Investment Tax Credit (ITC)” at http://programs.dsireusa.org/system/program/detail/658.
} 


\subsection{Community Solar}

A variety of LMI tenants may be precluded for procuring on-site solar, but they may be able to participate in community solar projects. These projects may also be of interest to LMI homeowners for a variety of reasons such as an unsuitable roof for PV, lower costs for PV adoption, and outsourced responsibility for operation and maintenance. As a result, state policymakers may wish to consider financing programs that focus on community solar as a means to address the LMI market more broadly.

Two of the key barriers to LMI participation in community solar projects are the up-front cost and long-term commitment. According to the Smart Electric Power Alliance (SEPA), 73\% of community solar projects required an upfront payment in 2015 (Chwastyk and Sterling n.d.). LMI customers typically cannot afford to make up-front payments to participate, which is one reason why 四

\section{Community Solar}

- The two key barriers to LMI participation in community solar projects are up-front cost and long-term commitment.

- Policymakers can address the cost barrier by providing financing directly to LMI participants or project developers.

- Policymakers considering participant financing could pursue:

- On-bill financing

- Loans

- Direct cash incentives

- Tax incentives

- LIHEAP/WAP.

- Policymakers considering developer financing could pursue:

- Direct cash incentives

- Production incentives

- Tax incentives

- Crowdfunding

$\circ$ Net metering.

customers may be concerned with entering into complex, long-term solar contracts that may not guarantee cost savings or include high exit fees.

Some states have established financing options to address cost barriers for participants by providing financing directly to the customer. In this scenario, states can be more assured that the LMI resident receives the full benefits of their subscription. In other cases, states have designed financial incentives to encourage developers to pursue LMI customers. Here, it is more difficult to ensure LMI residents benefit, depending on the financing option used. This section discusses each of these pathways in turn.

\subsubsection{Financing Options for Community Solar LMI Participants}

This section describes five leading financing approaches states could use for community solar participation to achieve their deployment goals. Table 7 summarizes the key advantages and disadvantages of each approach. 
Table 7. Advantages and Disadvantages of Selected Financing Structures for LMI Participants in Community Solar

\begin{tabular}{|c|c|c|}
\hline $\begin{array}{l}\text { Financing } \\
\text { Option }\end{array}$ & Advantages & Disadvantages \\
\hline On-bill Financing & $\begin{array}{l}\text { - Reduces or eliminates up-front cost to LMI } \\
\text { resident. } \\
\text { - May not require state funding. } \\
\text { - Many utilities have experience with this } \\
\text { financing structure from energy efficiency } \\
\text { programs. }\end{array}$ & $\begin{array}{l}\text { - New programs may require } \\
\text { legislative approval. } \\
\text { - Utilities may be reluctant to serve } \\
\text { as lenders. } \\
\text { - } \quad \text { Programs may be capped. } \\
\text { - Loan must be repaid despite PV } \\
\text { system performance. } \\
\text { - May not result in day-one savings } \\
\text { for LMI residents. }\end{array}$ \\
\hline Loans & $\begin{array}{l}\text { - Significantly reduces or eliminates up-front } \\
\text { cost to resident. } \\
\text { - May open up private capital markets if state } \\
\text { loan loss reserve program is in place }\end{array}$ & $\begin{array}{l}\text { - Low-interest loan programs may } \\
\text { require the involvement of the state. } \\
\text { - Higher cost to taxpayers than some } \\
\text { other options. } \\
\text { - } \quad \text { LMI residents must pay interest that } \\
\text { can limit benefits. } \\
\text { - } \quad \text { LMI residents may avoid loans for } \\
\text { nonessential purchases. } \\
\text { - Loan must be repaid despite PV } \\
\text { system performance. } \\
\text { - Loan terms may still not be } \\
\text { favorable enough to warrant LMI } \\
\text { participation. }\end{array}$ \\
\hline $\begin{array}{l}\text { Direct Cash } \\
\text { Incentives }\end{array}$ & $\begin{array}{l}\text { - Can reduce or eliminate the up-front cost as } \\
\text { well as ongoing payments. } \\
\text { - Some model programs are in place. } \\
\text { - Can encourage developers to seek LMI } \\
\text { subscribers. }\end{array}$ & $\begin{array}{l}\text { - Requires significant state } \\
\text { investment. } \\
\text { - } \quad \text { May require legislative approval. } \\
\text { - } \quad \text { May not cover full cost of resident } \\
\text { participation. }\end{array}$ \\
\hline Tax Incentives & $\begin{array}{l}\text { - Third-party access (typically banks) to tax } \\
\text { incentives may reduce or eliminate up-front } \\
\text { cost payments. } \\
\text { - One example of this approach has been } \\
\text { successfully deployed. } \\
\text { - Relies on private investment. } \\
\text { - Does not require legislative approval. }\end{array}$ & $\begin{array}{l}\text { - Relies on voluntary action of third- } \\
\text { parties such as banks. } \\
\text { - May be an unreliable source of } \\
\text { funding. } \\
\text { - Solar projects must compete with } \\
\text { other funding priorities. }\end{array}$ \\
\hline LIHEAP/WAP & $\begin{array}{l}\text { - Eliminates the up-front cost to LMI resident. } \\
\text { - LMI resident receives all the benefit of PV } \\
\text { adoption at no cost. }\end{array}$ & $\begin{array}{l}\text { - } \quad \text { Relies on federal and state funding. } \\
\text { DOE approval is required for WAP } \\
\text { - } \text { funds. } \\
\text { - } \text { Significant. } \\
\text { - Requires significant state } \\
\text { implementation capacity. } \\
\text { - } \quad \text { Limited in-the-field examples. } \\
\text { - Housing provider must commit } \\
\text { capital to the projects. } \\
\text { - Providers may wish to pursue other } \\
\text { more favorable financing options. }\end{array}$ \\
\hline
\end{tabular}


On-bill financing has been used on a limited basis to provide LMI customers with access to community solar. One example is a project developed by Grand Valley Power Cooperative and GRID Alternatives in Colorado that allows an on-bill financing option for LMI customers (Kaufmann 2015). In 2015, the program had limited participation $(<50 \%)$, which may be a result of the extra cost in the early years of the program. The program applies a $\$ 15$ fixed charged each month for the first five years of a customer's participation, while the community solar system provides $\$ 4$ per month in bill credits (Grand Valley Power Cooperative N.d.). After the first five years, the customer stops paying the $\$ 15 /$ month fee and continues to receive the bill credits.

This approach may be acceptable for moderate-income customers, while lower-income customers may not be willing or able to afford the higher costs in the near term. For this reason, on-bill financing structures that foster more widespread LMI adoption may need to ensure savings at the outset for participants. Ensuring savings from the outset may be difficult and require some state or other third-party involvement to reduce costs.

As is the case with other on-bill financing programs, states may also need to adopt legislation to enable this to be an option for either on- and off-site PV projects. If a program is launched, states might not be required to commit significant time and resources towards administration, given that utilities would likely manage the programs. However, utilities may be concerned with serving as a lender and devising new billing systems, which could influence deployment.

Low-interest loans have also been used by some states to help LMI community solar participants cover the up-front subscription cost. For example, Massachusetts has a Solar Loan Program that provides lower interest loans than the private market and will pay down $20 \%-30 \%$ of the project cost for LMI customers, depending on the customer's median income (Massachusetts Department of Energy Resources 2015). Loans will reduce the up-front cost of the system, but attention must be paid to the ongoing loan payments and the bill credits that an LMI customer receives. If the loan payments meet or exceed solar related bill credits, the LMI customer may not be able to afford to invest in a subscription. Even under favorable terms, LMI customers may still be hesitant to take a loan for a nonessential expenditure. This hesitancy could require states to make investments in educating potential LMI customers.

There are some benefits to the state from adopting loan programs relative to other options. For example, loan programs that leverage at least some private capital, may cost less than direct cash incentive programs. The state may encourage more private investment through developing a loan loss reserve backstop, as is the case in Massachusetts. ${ }^{23}$ However, high customer default rates would increase costs to the state, through payments to lenders from loan loss reserve accounts. In addition, there are limits on the total investment that the state can support, as is the case with direct cash incentives, which can limit the impact of this program. Finally, though states may partner with private banks, loan programs may still require significant state resources for oversight and implementation.

Direct-cash incentives have also been used to incentivize LMI customer participation in community solar projects. For example, Rhode Island has allocated $\$ 600,000$ to support $\$ 500$

\footnotetext{
${ }^{23}$ A loan loss reserve account can be used to offset losses from defaulted loans (Massachusetts Department of Energy Resources 2015).
} 
grants for each LMI customer that participates in a community solar project and $\$ 300$ for all other residential customers (Rhode Island Commerce Corporation 2017). These grants are used to offset subscription fees. This and other cash incentives could be used to reduce the up-front cost as well as ongoing payments for eligible LMI customers. The key challenge with this approach is that it requires state funds and thus may require legislative approval. In addition, it may be difficult to determine how much of a cash incentive is necessary to foster LMI resident participation, and maintain subscriptions after grants are fully paid out. There are also significant cost and administration requirements for the state to administer direct cash incentive programs.

Tax incentives, particularly incentives to private banks may be another option for financing LMI customer participation in community solar. Some banks may be interested in funding LMI subscriptions in community solar as a means to fulfill their Community Reinvestment Act obligation to serve the needs of borrowers in their communities. ${ }^{24}$ If banks donate community solar shares to LMI subscribers, they may apply for a tax deduction or include the project in their broader community reinvestment portfolio. For example, Alpine Bank in Colorado purchased a 25-kilowatt subscription at a solar array located in Summit County and donated the PV generation to Summit County's Family and Intercultural Resource Center (Reuter 2016). The bank also used that donation to offset its tax liabilities (Mendelsohn 2016). The center uses the proceeds from the project's generation to subsidize the energy bills of LMI families. This approach has three key benefits: it eliminates the up-front and ongoing costs for LMI customer participation, relies on private capital for the investment, and does not require state legislative activity. The fundamental challenge is that this approach relies on voluntary action from private lenders and thus may not be a reliable funding source. States could play a role in encouraging local and regional banks to consider financing more LMI projects in their states.

LIHEAP/WAP funds may potentially be used to support LMI customer participation in community solar. $15 \%$ of a state's LIHEAP funds may be used for weatherization projects. However, these funds cannot be used for projects that constitute new construction, so it may not be possible to finance a new community solar project. ${ }^{25}$ The remaining $85 \%$ of federal LIHEAP funds are used to offer energy bill assistance to LMI customers. It might be possible that these funds could be used to pay for monthly LMI subscriptions to existing projects. However, LIHEAP funds have not yet been used for a community solar subscription.

In comparison, WAP funds could potentially be used to cover the up-front cost of community solar subscriptions, but federal dollars have not been used in this way to date. ${ }^{26}$ If community solar projects are eligible for either funding source this financing approach offers some of the same benefits as in other contexts., However, opening this pathway would require significant time and resources.

\footnotetext{
${ }^{24}$ See "Community Reinvestment Act: Interagency Questions and Answers Regarding Community Reinvestments Guidance (12 CFR Part 345)” at https:/www.gpo.gov/fdsys/pkg/FR-2016-07-25/pdf/2016-16693.pdf.

${ }^{25}$ Recall, LIHEAP dollars can be used for retrofitting an existing home with rooftop PV.

${ }^{26}$ California plans to use state cap and trade dollars to launch a weatherization-based community solar pilot (California Department of Community Services and Development 2017). This program might serve as a model for how states could use federal weatherization dollars to deploy community solar for LMI residents.
} 


\subsubsection{Financing Options for Community Solar Developers}

Outside of financing individual subscriptions for LMI participants, states have also created financial incentives for community solar developers to pursue LMI customers. This section discusses five top financing approaches to encourage community solar through incentives to providers. Table 8 summarizes the advantages and disadvantages of each approach.

\section{Table 8. Advantages and Disadvantages of Selected Financing Structures for Community Solar Developers}

\begin{tabular}{|c|c|c|}
\hline $\begin{array}{l}\text { Financing } \\
\text { Option }\end{array}$ & Advantages & Disadvantages \\
\hline $\begin{array}{l}\text { Direct cash } \\
\text { incentives }\end{array}$ & $\begin{array}{l}\text { - May reduce up-front costs to developer } \\
\text { and LMI subscriber. } \\
\text { - May foster private developer interest or } \\
\text { collaboration. }\end{array}$ & $\begin{array}{l}\text { - } \quad \text { Significant cost to state. } \\
\text { - } \quad \text { Potential funding volatility. } \\
\text { - } \text { May require legislative approval. }\end{array}$ \\
\hline $\begin{array}{l}\text { Production } \\
\text { Incentives }\end{array}$ & $\begin{array}{l}\text { - May incentivize third-party developers to } \\
\text { subscribe LMI customers. } \\
\text { - This could result in lower up-front costs for } \\
\text { LMI customers and less impact on other } \\
\text { non-LMI subscribers. }\end{array}$ & $\begin{array}{l}\text { - May require significant state funding. } \\
\text { - Incentives may not be high enough to } \\
\text { encourage developers to reach out to } \\
\text { LMI customers. } \\
\text { - Program caps if met could limit future } \\
\text { LMI participation. }\end{array}$ \\
\hline Tax Incentives & $\begin{array}{l}\text { - Reduces the cost of a community solar } \\
\text { project. } \\
\text { - May not require state investment. }\end{array}$ & $\begin{array}{l}\text { Existing federal incentives do not } \\
\text { require LMI participation in projects. } \\
\text { - There are no examples of this } \\
\text { approach being used. } \\
\text { - Other incentives to support LMI } \\
\text { participation may be necessary. }\end{array}$ \\
\hline Crowdfunding & $\begin{array}{l}\text { Relies on private, largely non-investor } \\
\text { capital. } \\
\text { - Does not require state funding. }\end{array}$ & $\begin{array}{l}\text { - Relies on voluntary capital. } \\
\text { - } \quad \text { Funding may be unreliable. } \\
\text { - It may only be appropriate for certain } \\
\text { projects. }\end{array}$ \\
\hline Net Metering & $\begin{array}{l}\text { - Could encourage developers to seek LMI } \\
\text { customer participation. }\end{array}$ & $\begin{array}{l}\text { - Net metering has not been used to } \\
\text { incentive LMI participation in } \\
\text { community solar. } \\
\text { - Higher net metering credit could have } \\
\text { impacts on other ratepayers } \\
\text { - Likely requires legislative approval } \\
\text { - Incentive may not be enough to spark } \\
\text { - } \quad \text { developer interest or LMI participation } \\
\text { - Programs may be capped }\end{array}$ \\
\hline
\end{tabular}

Direct-cash incentives have been developed by states to deploy community solar for LMI customers. The most notable example is the $\$ 1.2$ million grant from the Colorado Energy Office (CEO) to GRID Alternatives in 2015 for LMI community solar demonstration projects (Phelan 2015). The grant required a 2:1 partner match from participating utilities. Six community solar projects have been constructed across six electric cooperatives in the state of Colorado (Colorado Energy Office 2017). Subscriptions are offered to eligible LMI customers at no cost, and those customers receive bill credits to reduce their energy burden. The benefit of this arrangement is the elimination of the up-front cost for LMI participants and projects that are exclusively used to 
meet LMI customers. However, the use of substantial subsidies has significant cost to the state. In addition, once the grant money is used, it is unclear that community solar developers will continue to pursue LMI customers, thereby limiting the market potential for this approach.

Production incentives have also been used to incentivize LMI participation in solar projects. For example, the proposed Solar Massachusetts Renewable Target would include an added incentive for LMI participation in community solar projects. ${ }^{27}$ These incentives may defray some of the costs to developers to include LMI participants in solar programs and increase participation. However, this option also comes with increased costs to the state and may be subject to incentive expenditure caps. In addition, it is unclear whether the value of the adder would cover the full cost of LMI participants or if some of these costs might be spread across other participants in the project.

Tax incentives and specifically those tailored to fostering economic development in LMI communities, such as the federal New Markets Tax Credit, could also be used to support community solar projects. The New Markets Tax Credit provides investors a $39 \%$ tax credit for qualifying economic development expenses in census tracts with a poverty rate over $20 \%{ }^{28}$ This tax credit could be used to encourage developers to construct projects in LMI communities and potentially subscribe LMI customers. Moreover, this incentive in particular does not require state investment. Though this tax credit has been used to deploy solar (U.S. Department of Treasury 2011), we could not find in-the-field examples of its use for community solar. Ultimately, relying on this federal incentive would not require any state investment. However, the developer would also not be required to subscribe LMI customers. Thus, additional state financing or incentives to support LMI participation may be necessary.

Crowdfunding may be another option to encourage a community solar developer to construct an LMI project. Though crowdfunding has not been used for a community solar project to date, it has been used for installing rooftop PV on Serenity House, a community-outreach center in a LMI neighborhood in North Philadelphia (Serenity Soular N.d.). The Serenity House, partnered with RE-volv, a company that specializes in crowdfunding for solar projects (RE-volv N.d.). It is possible that a similar approach could be used to pay developers to construct community solar projects that serve LMI customers. The benefit is that it does not rely on state funding, does not require legislative approval, or other state resources. The key drawback here is that crowdfunding is voluntary and funding is unreliable; therefore, crowdfunding may not achieve widespread access to solar for LMI customers.

Net metering programs could also be structured to encourage community solar developers to pursue projects with LMI subscriptions. For example, Mississippi includes a \$0.02 per kilowatthour adder for certain LMI customers to enroll in net metering programs offered by Entergy Mississippi and Mississippi Power. ${ }^{29}$ Other states could use a similar approach in their net

\footnotetext{
${ }^{27}$ See "225 CMR: Department of Energy Resources: 225 CMR 20.00: Solar Massachusetts Renewable Target (Smart) Program" at http://www.mass.gov/eea/docs/doer/rps-aps/225-cmr-20-00-draft.pdf.

${ }^{28}$ See "New Markets Tax Credit Program" at https://www.cdfifund.gov/programs-training/Programs/new-marketstax-credit/Pages/default.aspx.

${ }^{29}$ These utilities are no longer required to offer this incentive after the first 1,000 customers enroll. See the NC Clean Energy Technology Center's "Net Metering, Program Overview" at http://programs.dsireusa.org/system/program/detail/5841.
} 
metering programs to incentivize LMI customer participation in community solar programs. This incentive could be shared with developers to further reduce the costs to acquire LMI customers. Another consideration is that the net metering incentive may not be enough to encourage developers to seek LMI customers and program participation may be capped. 


\section{Summary Matrix of Financing Options}

Each LMI housing type has unique characteristics that influence the type of financing options that may be best to foster on-site or community solar projects. Depending on the context, the most appropriate financing options may be directed at residents, landlords, or community solar project developers.

Table 9 summarizes the top financing options by resident or building provider for the various housing types based on those that provide the most impact on LMI residents. The impact of financing options is not equal nor is the state cost to implement them. To get a sense of these tradeoffs, we discuss the financing options that rose to the top most frequently in our study.

\section{Table 9. Comparison of First Tier Financing Options by Resident, Housing Provider, or Developer (in yellow)}

\begin{tabular}{|c|c|c|c|c|c|}
\hline $\begin{array}{l}\text { Financing } \\
\text { Option }\end{array}$ & $\begin{array}{l}\text { Single-Family } \\
\text { Housing } \\
\text { (Owner- } \\
\text { Occupied) }\end{array}$ & $\begin{array}{l}\text { Multifamily } \\
\text { Housing } \\
\text { Provider }\end{array}$ & $\begin{array}{l}\text { Manufactured } \\
\text { Housing } \\
\text { Provider }\end{array}$ & $\begin{array}{c}\text { Any LMI Tenant } \\
\text { or Homeowner } \\
\text { (Community } \\
\text { Solar) }\end{array}$ & $\begin{array}{c}\text { Community } \\
\text { Solar } \\
\text { Developer }\end{array}$ \\
\hline \multicolumn{6}{|l|}{$\begin{array}{l}\text { Bulk } \\
\text { Purchasing }\end{array}$} \\
\hline \multicolumn{6}{|l|}{$\begin{array}{l}\text { Capital } \\
\text { Refinancing }\end{array}$} \\
\hline \multicolumn{6}{|l|}{ Crowdfunding } \\
\hline \multicolumn{6}{|l|}{$\begin{array}{l}\text { Direct Cash } \\
\text { Incentives }\end{array}$} \\
\hline \multicolumn{6}{|l|}{ Solar Hosting } \\
\hline \multicolumn{6}{|l|}{ Loans } \\
\hline \multicolumn{6}{|l|}{ LIHEAP/WAPa } \\
\hline \multicolumn{6}{|l|}{ Net Metering } \\
\hline \multicolumn{6}{|l|}{$\begin{array}{l}\text { On-bill } \\
\text { Financing }\end{array}$} \\
\hline \multicolumn{6}{|l|}{ PACE } \\
\hline \multicolumn{6}{|l|}{$\begin{array}{l}\text { Production } \\
\text { Incentives }\end{array}$} \\
\hline \multicolumn{6}{|l|}{ Tax Incentives } \\
\hline $\begin{array}{l}\text { Third-party } \\
\text { Leasing/ESA }\end{array}$ & & & & & \\
\hline
\end{tabular}


LIHEAP/WAP and direct cash incentives are among the top financing options across four of the five categories in Table 9. LIHEAP/WAP-supported projects can offer the most direct benefit to LMI customers, as these programs are designed such that an LMI resident does not pay for the investment but enjoys the full benefit of the PV system. Direct cash incentives are also attractive financing options that can be used to achieve the same goal. However, both programs require significant investments from the state to implement.

Three other financing options - on-bill financing, tax incentives, and third-party leasing/ESA are among the leading options across housing types (see Table 9). On-bill financing (where the up-front cost is eliminated and future payments are derived from savings) is appealing because it does not require any investment by the LMI resident. Third-party leasing/ESA might also be structured in this way and might allow for residents to benefit from tax incentives indirectly. Finally, tax incentives may be most appropriate for building owners or third-parties to facilitate LMI solar adoption as opposed to being used by residents themselves. Each of these options may require less direct involvement by the state in implementation than other options, but the state may need to be involved to ensure LMI residents can effectively access these financing options.

Finally, loans and PACE are among the top financing options for multifamily or manufactured housing. These two financing options reduce the up-front payment for LMI customers, but they may require ongoing payments with interest that could be burdensome. The loan terms, particularly for PACE, can also reduce the benefit that LMI residents receive from their investments because of higher financing costs. Low interest loan programs can offer more desirable financing for LMI customers, but often require more subsidies from the state.

Though the focus of this report is on the top financing options for residents and affordable housing providers, in reality, LMI projects rely on a variety of financing options for deployment. For example, Colorado's LMI rooftop PV program leverages WAP and LIHEAP dollars as well as production and direct cash incentives. Moreover, it is not uncommon that a third-party leasing/ESA contract would leverage available net metering credits and tax incentives. Thus, a project's individual context may dictate what types of incentives are most appropriate.

Given that multiple types of incentives may be needed to drive LMI solar deployment, Table 10 lists the top tier financing options discussed in detail in this report, as well as the other financing tools that could be used in each housing category. The table shows that most of the financing options discussed in Section 2 could be applied across all categories, with a few exceptions. For example, capital refinancing is reserved for large multifamily housing providers and community solar developers are precluded from a variety of financing options that are tailored specifically to residents or landlords. 


\section{Table 10. Comparison of Financing Options by Resident, Housing Provider, or Developer}

\begin{tabular}{|c|c|c|c|c|c|}
\hline $\begin{array}{l}\text { Financing } \\
\text { Option }\end{array}$ & $\begin{array}{l}\text { Single-Family } \\
\text { Housing } \\
\text { (Owner- } \\
\text { Occupied) }\end{array}$ & $\begin{array}{l}\text { Multifamily } \\
\text { Housing } \\
\text { Provider }\end{array}$ & $\begin{array}{l}\text { Manufactured } \\
\text { Housing } \\
\text { Provider }\end{array}$ & $\begin{array}{c}\text { Any LMI Tenant } \\
\text { or Homeowner } \\
\text { (Community } \\
\text { Solar) }\end{array}$ & $\begin{array}{l}\text { Community } \\
\text { Solar } \\
\text { Developer }\end{array}$ \\
\hline \multicolumn{6}{|l|}{$\begin{array}{l}\text { Bulk } \\
\text { Purchasing }\end{array}$} \\
\hline \multicolumn{6}{|l|}{$\begin{array}{l}\text { Capital } \\
\text { Refinancing }\end{array}$} \\
\hline \multicolumn{6}{|l|}{ Crowdfunding } \\
\hline \multicolumn{6}{|l|}{$\begin{array}{l}\text { Direct Cash } \\
\text { Incentives }\end{array}$} \\
\hline \multicolumn{6}{|l|}{ Solar Hosting } \\
\hline \multicolumn{6}{|l|}{ Loans } \\
\hline \multicolumn{6}{|l|}{ LIHEAP/WAPa } \\
\hline \multicolumn{6}{|l|}{ Net Metering } \\
\hline \multicolumn{6}{|l|}{$\begin{array}{l}\text { On-bill } \\
\text { Financing }\end{array}$} \\
\hline \multicolumn{6}{|l|}{ PACE } \\
\hline \multicolumn{6}{|l|}{$\begin{array}{l}\text { Production } \\
\text { Incentives }\end{array}$} \\
\hline \multicolumn{6}{|l|}{ Tax Incentives } \\
\hline \multicolumn{6}{|l|}{$\begin{array}{l}\text { Third-party } \\
\text { Leasing/ESA }\end{array}$} \\
\hline \multicolumn{4}{|c|}{ a Low-Income Home Energy Assistance Program/Weatherization Assistance Program } & \multicolumn{2}{|c|}{$\underset{N / A}{\longrightarrow}$ SecondTier First Tier } \\
\hline
\end{tabular}

In summary, a variety of financing options are available to support LMI adoption of on-site PV or community solar. The most effective financing strategies can depend on a resident's homeownership status, housing type, and presence of other LMI subsidies. Typically, the top financing options also require significant investment from the state. As a result, policymakers may need to weigh these tradeoffs in relation to achieving their LMI PV deployment goals. 


\section{References}

APS (Arizona Public Service). 2017. "Solar partner program: Program is Currently Full." https://www.aps.com/en/ourcompany/aboutus/investmentinrenewableenergy/Pages/solarpartner.aspx. Date Accessed 11/20/2017.

Barbose, Galen, Naïm Darghouth, Ryan Wiser, Ben Hoen, and Dev Millstein. 2017. Income Trends among Residential Solar Adopters. Phase 1 Analysis for CESA SES Project. April 11, 2017.

Beal, Tim, Jim Hartman, Jonathan Koehn, Susie Strife. 2015. Nation's First Large-Scale Solar Garden Dedicated 100\% to Affordable Housing Providers. Press Release.

https://boulderhousing.org/sites/default/files/page attachments/2015-0921 solar garden dedicated to affordable housing providers.pdf.

California Public Utilities Commission. 2017a. CSI Single-Family Affordable Solar Homes (SASH) Program. http://www.cpuc.ca.gov/General.aspx?id=3043.

California Public Utilities Commission. 2017b. CSI Multifamily Affordable Solar Housing (MASH) Program. http://www.cpuc.ca.gov/General.aspx?id=3752.

Center for Social Inclusion, GRID Alternatives, and Vote Solar. 2016. Low-income Solar Policy Guide. http://www.lowincomesolar.org/wp-content/uploads/2016/03/Low-Income-Solar-PolicyGuide_3.11.16.pdf.

Chwastyk, Dan and John Sterling. N.d. Community Solar Program Design Models. https://s3.amazonaws.com/fonteva-customermedia/00Do0000000Yi66EAC/Community\%20Solar\%20Program\%20Design\%20Models.pdf.

CleanFund Commercial PACE Capital. 2017. SolarPACE TM financing by CleanFund is becoming a key driver of growth for the commercial solar industry. http://www.cleanfund.com/solarpace-drivering-growth-for-commercial-solar-industry/.

Clean Energy Advisory Council. 2017. Report on Alternative Approaches to Providing Low and Moderate Income (LMI) Clean Energy Services. http://documents.dps.ny.gov/public/Common/ViewDoc.aspx?.DocRefId=\{F84BD434-DD25483F-B481-CCDD92B0A187?.

Clean Energy Group. 2017. McKnight Lane Affordable Housing Development: Resilient, NetZero, Low-Income Rental Housing in Rural Vermont. http://www.cleanegroup.org/wpcontent/uploads/McKnight-Project-Data.pdf.

Connecticut Green Bank. 2017a. "Homeowners." http://www.ctgreenbank.com/programs/homeowners/.

Connecticut Green Bank. 2017b. “About Us.” http://www.ctgreenbank.com/about-us-2017/. 
Connecticut Green Bank. 2017c. Discover savings with green energy.

http://www.ctgreenbank.com/wp-content/uploads/2017/04/Multifamily Sheet 021517.pdf.

Connecticut Green Bank. 2017c. "Homeowners."

http:/www.ctgreenbank.com/programs/homeowners/.

Connecticut Green Bank. 2016. C-PACE Program Guidelines. Version 5. Released January 19, 2016. http://www.cpace.com/assets/pdf/C-PACE Program Guidelines v5.pdf.

DOE (U.S. Department of Energy). 2017a. The Use of Solar PV in WAP. WAP Memorandum 024. https://energy.gov/sites/prod/files/2017/01/f34/WAPMEMO\%20024\%201.17.17.pdf.

DOE (U.S. Department of Energy). 2017b. "Retrofit incentives for Multifamily Buildings." https://energy.gov/eere/wipo/retrofit-incentives-multifamily-buildings.

EIA (U.S. Energy Information Administration). 2017. "Residential Energy Consumption Survey (RECS).” https://www.eia.gov/consumption/residential/data/2015/hc/php/hc2.1.php.

Executive Office of Energy and Environmental Affairs. 2017a. Massachusetts Solar Loan Program. Commonwealth of Massachusetts. http://www.mass.gov/eea/energy-utilities-cleantech/renewable-energy/solar/residential-solar-loan-program.html.

Executive Office of Energy and Environmental Affairs. 2017b. About the Solar Carve-Out II Program. Commonwealth of Massachusetts. http://www.mass.gov/eea/energy-utilities-cleantech/renewable-energy/solar/rps-solar-carve-out-2/about-solar-carve-out-ii.html.

Grand Valley Power Cooperative. N.d. "Solar Farm." http://www.gvp.org/content/solar-farm.

Higgins, Heatheryn, Howard Brooks, and Patrice Lehermeier. 2016. Colorado Launches First Low-Income Rooftop Solar Project within its Weatherization Assistance Program. Colorado Energy Office.

https://www.colorado.gov/pacific/sites/default/files/atoms/files/First\%20WAP\%20LowIncome \%20Rooftop $\% 20$ Solar\%20Project\%20.pdf.

Honeyman, C., MJ Shia, Sarah Krulewitz. 2017. U.S. Community Solar Outlook 2017. GTM Research.

HUD Exchange. (U.S. Department of Housing and Urban Development). 2017a. "Rental Assistance.” https://portal.hud.gov/hudportal/HUD?src=/topics/rental assistance.

HUD Exchange (U.S. Department of Housing and Urban Development). 2017b. "HOME Rent Limits." https://www.hudexchange.info/programs/home/home-rent-limits/.

HUD (U.S. Department of Housing and Urban Development). 2017c. "HUD's Public Housing Program." https://portal.hud.gov/hudportal/HUD?src=/topics/rental assistance/phprog.

HUD (U.S. Department of Housing and Urban Development). 2017d. "Solar Project Development for Public Housing Authorities Webinar." 
https://www.hudexchange.info/trainings/courses/solar-project-development-for-public-housingauthorities-webinar/1963/.

HUD (U.S. Department of Housing and Urban Development). 2017e. "Renewal of Section 8 Project-Based Rental Assistance."

https://portal.hud.gov/hudportal/HUD?src=/hudprograms/rs8pbra.

HUD (U.S. Department of Housing and Urban Development). 2017f. "Low-income Housing Tax Credits." Revised 7/10/2017. https://www.huduser.gov/portal/datasets/lihtc.html.

HUD (U.S. Department of Housing and Urban Development). 2017g. "Energy Performance Contracting."

https://portal.hud.gov/hudportal/HUD?src=/program_offices/public_indian_housing/programs/p $\underline{\mathrm{h} / \text { phecc/eperformance. }}$.

HUD (U.S. Department of Housing and Urban Development). 2017h. Background on New Guidance on Multi-family PACE in California.

https://www.hudexchange.info/resources/documents/Background-on-New-Guidance-onMultifamily-PACE-in-California.pdf.

HUD (U.S. Department of Housing and Urban Development). 2017i. Mortgage Insurance for Rental and Cooperative Housing: Section 221(d)(4). https://www.hud.gov/program offices/housing/mfh/progdesc/rentcoophsg221d3n4.

HUD (U.S. Department of Housing and Urban Development). 2017j. Renew300 Solar Project Development for Public Housing Authorities. Webinar: May 31, 2017. https://www.hudexchange.info/course-content/solar-project-development-for-public-housingauthorities-webinar/Solar-Project-Development-for-PHAs-webinar-slides.pdf.

HUD (U.S. Department of Housing and Urban Development). 2015. "Administrative Guidance for Multifamily Property Assessed Clean Energy (PACE) in California." Memorandum. Jan. 29, 2015. https://portal.hud.gov/hudportal/documents/huddoc?id=MF_PACE_CA_Memo.pdf.

Internal Revenue Service. 2017. 38. Other Credits. https://www.irs.gov/publications/p17/ch38.html\#en US 2016 publink1000174999.

Kaufmann K. 2015. Low-income community solar in Colorado: Hand-up, not handout. Smart Electric Power Alliance. Smart Electric Power Alliance. https://sepapower.org/knowledge/lowincome-community-solar-in-colorado-hand-up-not-handout/.

Leventis, Greg, Emily Martin Fadrhonc, Chris Kramer, Charles Goldman. 2016. Current Practices in Efficiency Financing: An Overview for State and Local Governments. Lawrence Berkeley National Laboratory. LBNL-1006406. https://emp.lbl.gov/sites/all/files/lbnl1006406.pdf.

Lowder, Travis. 2017. Publicly Supported Solar Loan Programs. A Guide for States and Municipalities. Clean Energy States Alliance. https://www.cesa.org/assets/2017-Files/PubliclySupported-Solar-Loan-Programs.pdf. 
Lotus Engineering and Sustainability LLC. 2015. Analysis of the Fulfillment of the Low-income Carve-Out for Community Solar Subscriber Organizations.

https://www.colorado.gov/pacific/sites/default/files/atoms/files/Low-

Income \%20Community\%20Solar\%20Report-CEO.pdf.

Massachusetts Department of Energy Resources. 2015 Massachusetts Residential Solar Loan Program. January 6, 2015. http://www.mass.gov/eea/docs/doer/renewables/solar/mass-solarloan-program-final-design.pdf.

Mendelsohn, Mike. 2016. "A Colorado Bank Offers a Powerful Case Study for Supporting Solar in Low-Moderate Income Communities." Greentech Media, October 28, 2016.

https://www.greentechmedia.com/articles/read/community-banks-and-community-solar-to-servethe-low-moderate-income-commun\#gs.5cvKhnE.

National Coalition of State Legislatures (NCSL). 2015. "On-bill Financing: Cost-free Energy Efficiency Improvements.” http://www.ncsl.org/research/energy/on-bill-financing-cost-freeenergy-efficiency-improvements.aspx.

Paulos, Bentham. Bringing the Benefits of Solar Energy to Low-Income Consumers: A Guide for States \& Municipalities. Clean Energy States Alliance. http://www.cesa.org/assets/2017Files/Bringing-the-Benefits-of-Solar-to-Low-Income-Consumers.pdf.

Penn, Ivan. 2016. "The DWP is expanding its rooftop panel program to the 'solar desert' to meet its energy goals." The Los Angeles Times, November 23, 2016.

http://www.latimes.com/business/la-fi-dwp-solar-deserts-20161122-story.html.

Perea, Austin, Cory Honeyman, Shayle Kann, Allison Mond, MJ Shiao, Jade Jones, Scott Moskowitz, Ben Gallagher, Colin Smith, Shawn Rumery, Aaron Holm, Katie O'Brien, and Justin Baca. 2017. U.S. Solar Market Insight Full Report Q2 2017. GTM Research.

Phelan, Karen. 2015. "Colorado Energy Office awards \$1.2 million grant funding to GRID Alternatives for low-income solar project." Press Release. https://www.colorado.gov/pacific/sites/default/files/atoms/files/Colorado $\% 20$ Energy $\% 200$ ffice $\% 20$ awards $\% 20 \% 241.2 \% 20$ million $\% 20$ grant $\% 20$ funding $\% 20$ to $\% 20$ GRID $\% 20$ Alternatives $\% 20 f$ or $\% 201$ ow-income $\% 20$ solar $\% 20$ project.pdf.

Philadelphia Energy Authority. 2017. LMI Solar Program. http://solarizephilly.org/solar-for-all/.

Reuter, Elise. 2016. "FIRC, Alpine Bank partner to bring local households a little bit of sunshine." June 7, 2016. http://www.summitdaily.com/news/business/firc-alpine-bank-partnerto-bring-local-households-a-little-bit-of-sunshine/.

Re-volv. N.d. "Serenity House.” https://re-volv.org/project/serenityhouse/.

Rhode Island Commerce Corporation. 2017. Community Renewables Request for Projects. http://commerceri.com/wp-content/uploads/2017/06/Community-Renewables-Requests-6.5.17MAIN.pdf. 
Ronen, Amit, Dor Hirsh Bar Gai, and Lucas Crampton. 2016. Can Electricity Rate Subsidies be Reallocated to Boost Low-Income Solar? George Washington Solar Institute.

http://solar.gwu.edu/file/2668/download.

Sanchez, Laura, Chaprece Henry, Sarah Ryan. 2016. PACE Financing Opportunities in the Affordable Housing Sector. Environmental Defense Fund. http://blogs.edf.org/texascleanairmatters/files/2016/11/PACE-for-Aff-Housing FINAL-111416EDF-KPT.pdf.

Serenity Soular. N.d. "Bringing Solar Energy and Green Jobs to North Philadelphia." http://serenitysoular.weebly.com/.

Sunrun. 2017. Sunrun Partners with GRID Alternatives to Finance Solar Projects for Lowincome Homeowners. http://investors.sunrun.com/news-releases/news-release-details/sunrunpartners-grid-alternatives-finance-solar-projects-low/.

U.S. Census. 2017. Quarterly Residential Vacancies and Homeownership, Second Quarter 2017. https://www.census.gov/housing/hvs/files/currenthvspress.pdf.

U.S. Department of Agriculture. N.d. Rural Housing Service. https://www.rd.usda.gov/aboutrd/agencies/rural-housing-service.

U.S. Department of the Treasury. 2011. Investing in Solar Energy Using the Public Welfare Investment Authority. Community Developments Investments. July.

https://www.occ.gov/publications/publications-by-type/other-publications-reports/cdinewsletter/cdi-investing-solar-engergy-2011.pdf.

U.S. Department of Treasury and Internal Revenue Service. 2016. "Utility Allowances Submetering." Federal Register. 81 FR (11104-11110). https://www.federalregister.gov/documents/2016/03/03/2016-04606/utility-allowancessubmetering.

White, Evan. 2012. Utilities in Federally Subsidized Housing. A Report on Efficiency, Utility Savings, and Consistency. Goldman School of Public Policy, UC Berkeley Law at Boalt Hall. http://aceee.org/files/pdf/resource/white utilities in federally subsidized housing 2012.pdf. 